\title{
From Employment Optional to “Employment First”: \\ Explaining Two Cases of State-level Disability Policy Change
}

\author{
Leanne S. Giordono* \\ Oregon State University
}

*Author contact information: giordonl@oregonstate.edu. Unpublished manuscript; please do not cite or circulate without permission from author. 


\begin{abstract}
Under the label "Supported Employment," services that promote competitive, integrated employment (CIE) for working-age adult with intellectual and developmental disabilities have been federally funded since the 1980s, alongside other more traditional day habilitation and segregated or sub-minimum wage employment services. However, since the early 2000s, over 30 states have adopted "Employment First” policy, prioritizing competitive, integrated employment (CIE) as the preferred outcome, and in some states, restricting alternative service options. And while disability researchers have made a considerable effort to understand system-level determinants of participation in CIE-focused services, little attention has been paid to the political factors driving these major changes in the overall policy mix. Moreover, the Employment First changes, which have attracted little public attention or controversy, vary considerably across states in timing, form and content, leading to the study's main research questions: 1) what do these policy changes look like; and 2) how can we explain both the occurrence of major policy changes and the variations in timing? The study uses primary and extant data in a two-case comparative approach, finding that major shifts in the policy mix were associated with similar combinations of subsystem attention and coalition-based activity, including stakeholder mobilization and strategic use of framing and narrative, as well as heightened political attention and bureaucrat advocacy. Moreover, the timing differences are related to coalition defection by members of the service provider community and high preexisting participation in supported employment services, which suggest a degree of path dependence in observed policy changes.
\end{abstract}

Keywords: Advocacy Coalition Framework, disability policy, employment, habilitation 


\section{$1.1 \quad$ Introduction}

Since 2000, over 30 states have adopted policy prioritizing competitive, integrated employment $(\mathrm{CIE})^{1}$ outcomes among the population of working-age adults with Intellectual and Developmental Disabilities (I/DD), typically under the label "Employment First” (Nord et al., 2013; Racino, 2015). Day Habilitation and Employment (DH\&E) services and supports for adult, working-age individuals with intellectual and developmental disability, which are intended to enable adults with I/DD to successfully live and work in their communities, are managed at the state level. However, they are nested in the broader system of cooperative federalism via the system of Medicaid Home- and Community-Based Services (HCBS) waivers, which provide the majority of funding for DH\&E systems (Agranoff, 2013; Gettings, 2011). In 2015, 610,000 individuals with I/DD received DH\&E services and supports nationwide, of whom 18\% received integrated employment services (Butterworth et al., 2016). States vary substantially in the degree to which eligible individuals participate in integrated employment services, from about $1 \%$ to 87\% (University of Massachusetts Boston, Institute on Community Inclusion, n.d.).

The state-level "Employment First” policy changes observed during the last two decades take multiple forms (legislative, executive and administrative directives), and include a combination of symbolic language, improved access to employment supports and/or incentivization of employment services and restrictions on facility-based and day activity services (Butterworth et al., 2016; Nord, 2014). The form of policy adoption also varies, with states passing new legislation, executive orders and/or administrative directives (LEAD Center, n.d.; Nord, 2014), as shown in Figure 1.

\footnotetext{
${ }^{1}$ CIE-focused services and supports include supported employment, integrated employment and customized employment, which typically prioritize work in integrated settings (i.e., alongside individuals without I/DD) and earning competitive wages. Other (non-CIE) services and supports typically include day habilitation, facilitybased employment (i.e., sheltered workshops), and sub-minimum wage jobs.
} 


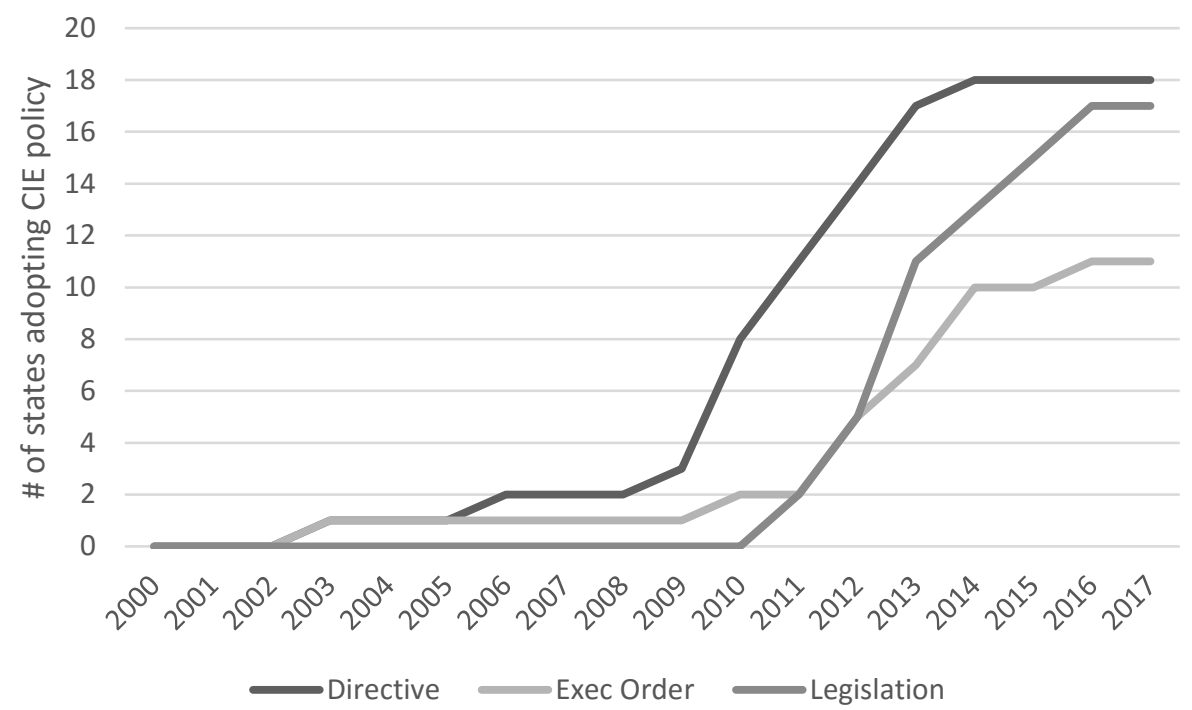

Figure 1: CIE-focused policy adoption (adapted from Nord, 2014 and expanded using LEAD Center data)

While state-level variation is not unexpected, we understand little about the conditions and causal mechanisms that result in state-level policy change in a federal context (Thompson and Burke, 2007). Furthermore, while the policy adoption distribution curves resemble a standard S-shaped curve typically associated with a national interaction model (Berry and Berry, 2017; Rogers, 1995), the variation in both the content and form of the changes and evidence of coalition activity (Giordono, 2019) suggests more than a simple policy diffusion process. These observations give rise to the primary research questions: 1) What does state-level CIE-focused policy change look like? 2) Why and how did CIE-focused policy change occur? and 3) Why did states vary in the timing of policy change?

Disability researchers point to a variety of systems-level factors, including policy change, that are expected to yield changes to individual employment outcomes (Butterworth et al., 2017; Hall et al., 2007). However, while the "systems change” model highlights policy change, it does not explicitly identify conditions that lead to policy change and tends to disregard political factors emphasized by the policy process literature. The policy process literature, in turn, finds evidence that traditional political factors, such as strategic action by organized interests (Itkonen, 2007, e.g., 2009), often influence disability-related policy. However, to date, policy process scholars rarely attend to disability policy and have not applied policy process frameworks to the CIE-focused changes observed in the DH\&E subsystem. 
This study theoretically leverages the Advocacy Coalition Framework (ACF) in a comparative research design to examine policy changes observed in two states' DH\&E subsystems, Washington and Pennsylvania. The two "diverse" cases were purposively selected because they reflect early and late policy change during the eighteen-year window from 19992017, providing a counterfactual to assess the conditions that lead to policy change (Gerring, 2008; Seawright and Gerring, 2008). Moreover, they are similar with respect to key characteristics, such as citizen ideology, welfare generosity and the presence of a rural/urban divide. The findings suggest that in both states, common factors leading to policy change include heightened subsystem attention and coalition-based use of stakeholder mobilization, strategic framing and narrative, as well as heightened political attention, and bureaucratic advocacy. The timing difference, however, is associated with the early defection of Washington service providers from the status quo coalition.

The study finds that major shifts in the policy mix were associated with similar combinations of subsystem attention and coalition-based activity, including stakeholder mobilization and strategic use of framing and narrative, as well as heightened political attention and bureaucrat advocacy. Moreover, the timing differences are associated with coalition defection by members of the service provider community and high pre-existing participation in supported employment services, which suggest a degree of path dependence in observed policy changes.

The study offers important implications for both disability policy and policy process research. From a disability policy perspective, the study highlights conditions under which major policy change is likely to occur, as well as the type of policy change (minor) that is more likely to be associated with policy-oriented learning. Federal agencies and disability researchers interested in supporting state-level policy change are likely to find these results relevant to their efforts. From a policy process perspective, the study offers a "non-traditional" application of the ACF to low salience conditions, which is more typically applied to high salience, contentious policy issues (Jenkins-Smith et al., 2017). The study also yields considerations for theory development, including potential refinements to our understanding of policy change.

\subsection{Leveraging Two Literatures to Understand CIE-focused Changes}

Two distinct, but complementary, literatures offer important insights into the observed CIE-focused policy changes: 1) disability research; 2) policy process research. 


\subsection{Disability Research}

Disability scholars have devoted substantial attention both to recent CIE-focused changes and to disability policy more broadly. Prior to 1985, most individuals with I/DD receiving waiver-funded services were served in segregated, unpaid day habilitation settings (Mcgaughey and Mank, 2001a). In the 1970s and early 1980s, new knowledge and successful demonstrations yielded growing nationwide interest in supported employment as an option for individuals with severe disabilities (Mcgaughey and Mank, 2001a). Between 1985 and 1996, federal grants had been provided to all but 2 states to support innovation and systems change in supported employment services and supports (Mcgaughey and Mank, 2001a, 2001b). Pennsylvania and Washington were among the first two cohorts of state-level grantees (Wehman et al., 1989). These efforts dovetailed with the establishment of Medicaid waivers that enabled states to shift services from facility-based settings to home and community-based settings, as well as the first decade of Individuals with Disabilities Education Act implementation (Agranoff, 2013; Gettings, 2011; Mcgaughey and Mank, 2001a).

Despite initial growth in the availability and participation in supported employment, researchers noted widespread variation among states (Mcgaughey and Mank, 2001a, 2001b) and a broad slowdown in state-level supported employment outcomes (Braddock et al., 2004; Butterworth et al., 1999; Mcgaughey and Mank, 2001a, 2001b; Rusch and Braddock, 2004). Early efforts to explain these trends are inconclusive and ultimately suggest that "systems change is complex” (Mcgaughey and Mank, 2001a: 221). Ultimately, disability researchers developed a new actor-driven, implementation-focused and goal-oriented Systems Change model that highlights 'context and catalysts,' 'strategies' and 'facilitators' (Hall et al., 2007), which is shown in Figure 2. ${ }^{2}$

\footnotetext{
2 The model was initially called the "Conceptual Model for High Performance Variables" but has since been referred to more commonly as a Systems Change model. I adopt similar terminology in this paper.
} 


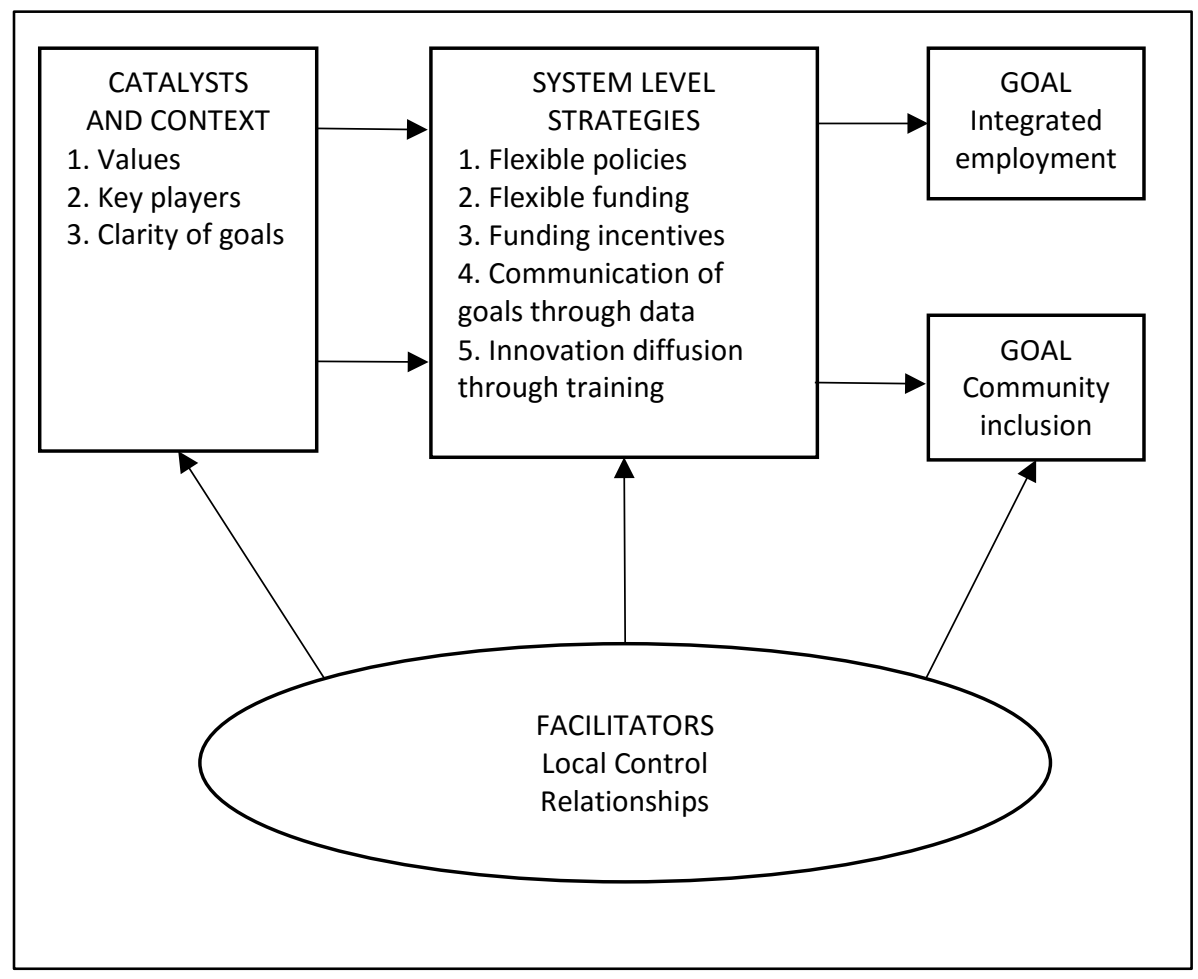

Figure 1: Systems Change Model (adapted from Hall et al., 2007)

The Systems Change model reflects researchers' observations about early adopters of CIE-focused policy (Hall et al., 2003, e.g., 2007). Since the development of that model, disability researchers have steadily engaged in evaluative research, yielding targeted lessons about systemlevel conditions, facilitators and barriers associated with goal achievement, continuing to emphasize the importance of leadership (Winsor et al., 2006); a 'backbone organization’ (Butterworth et al., 2017: 273), relationships (Butterworth et al., 2017; Tucker et al., 2017), funding mechanisms (Butterworth et al., 2008; Hall et al., 2011), and service provider transformation (Inge et al., 2018; Rogan and Rinne, 2011; Sulewski et al., 2017). They have also devoted considerable efforts to clarifying and promoting the model, often under the label “Employment First”. For example, multiple researchers describe the principles embodied by the Systems Change model (e.g., Kiernan et al., 2011; Martinez, 2013; Niemiec et al., 2009; Nord et al., 2013), as well as specific strategies (including policy changes) for achieving change, suggesting that disability researchers have reached a 'scientific consensus' around the value and feasibility of prioritizing CIE outcomes. The Systems Change model, however, lacks specification around the drivers, conditions or nature of expected policy changes. The model 
turns the lens on employment outcomes for individuals with disability, rather than the policy process itself, omitting reference to most of the political factors highlighted by the policy process literature, which are described below.

\subsection{Policy Process Research}

The policy process literature, which is the study of "how public policy is made" (Smith and Larimer, 2016: 93), frequently includes a focus on how and why policy changes. There have been relatively few applications of policy process theory to disability-related policy systems during the last two decades. However, existing applications suggest that a politically-oriented approach to understanding the disability policy system may yield fruitful insights for understanding the recent state-level changes. In particular, these studies suggest that disability policy change is frequently characterized by 1) activity by interest groups or coalitions with opposing policy preferences (Itkonen, 2007); and 2) use of standard political strategies to achieve policy change, including agenda-setting (Pettinicchio, 2013), problem definition (Itkonen, 2009; Jeon and Haider-Markel, 2001), venue-shopping (Nagel, 2006), framing and narrative (Itkonen, 2007; Jeon and Haider-Markel, 2001) and interest group mobilization (Shapiro, 1994). Most recently, in a study with direct relevance to this research, Giordono (2019) finds evidence of at least two competing advocacy coalitions, "Employment First” and “Choice,” in the Day Habilitation and Employment Services subsystem in Washington and Pennsylvania during the 2000-2017 study period.

This paper contends that the complementarities between the two literatures offer an opportunity to understand the process of state-level policy change in the context of the DH\&E systems. Specifically, the Advocacy Coalition Framework (ACF) accommodates most of the key elements of the Systems Change model, while placing the spotlight on CIE-focused policy change.

The ACF was developed by Sabatier and Jenkins-Smith in the early 1990s to explain policy change and learning (Sabatier, 1988; Sabatier and Jenkins-Smith, 1993; Weible et al., 2011) and has subsequently been applied in at least 240 publications (Pierce et al., 2017; Weible et al., 2009). The ACF posits that policy change and learning results from competition by advocacy coalitions to achieve policy preferences (Sabatier and Jenkins-Smith, 1999). Advocacy coalitions are composed of individuals who "share policy core beliefs and who coordinate their actions in a nontrivial manner to influence a policy subsystem” (Jenkins-Smith et al., 2017: 148). 
The policy subsystem can include a wide range of subsystem actors, including government staff, politicians, interest groups, consultants, scientists and others (Sabatier, 1988; Sabatier and Jenkins-Smith, 1993). Policy actors' beliefs are described in the context of a 3-tiered system: 1) deep core beliefs; 2) policy core beliefs; and 3) secondary core beliefs (Sabatier and JenkinsSmith, 1993).

In the context of the ACF, policy change includes revisions in policy core components of governmental programs, termination of programs, or launching of new programs. The ACF hypothesizes that several sources of policy change: 1) external perturbations; 2) internal events; 3) policy-oriented learning; and 4) negotiated agreement (Jenkins-Smith et al., 2017). Events can include changes to socioeconomic conditions, public opinion, systemic governing coalition(s), policies in other subsystems, or even changes to more stable parameters and long-term opportunity structures. The ACF also hypothesizes that major policy change is unlikely to occur while the advocacy coalition responsible for the original policy remains in power, except under conditions of hierarchical imposition (Jenkins-Smith et al., 2017). Other conditions expected to influence policy change include the overall context, coalition-specific resource use and political opportunity structures. See Figure 3 for an adapted version of the traditional ACF visual, which explicitly articulates coalition resources and related strategies. ${ }^{3}$ For simplicity, it eliminates the separation between short- and long-term coalition opportunity structures. Long-term opportunity structures are traditionally used by the ACF to accommodate variation in international political systems, whereas a comparison between two US states is unlikely to exhibit substantial differences in long-term political structures.

${ }^{3}$ This visual explicitly articulates coalition resources and related strategies. For clarity, it eliminates the role of long-term coalition opportunity structures, which are traditionally used to accommodate variation in international political systems. A comparison between two US states is unlikely to yield substantial differences to long-term opportunity structures. 


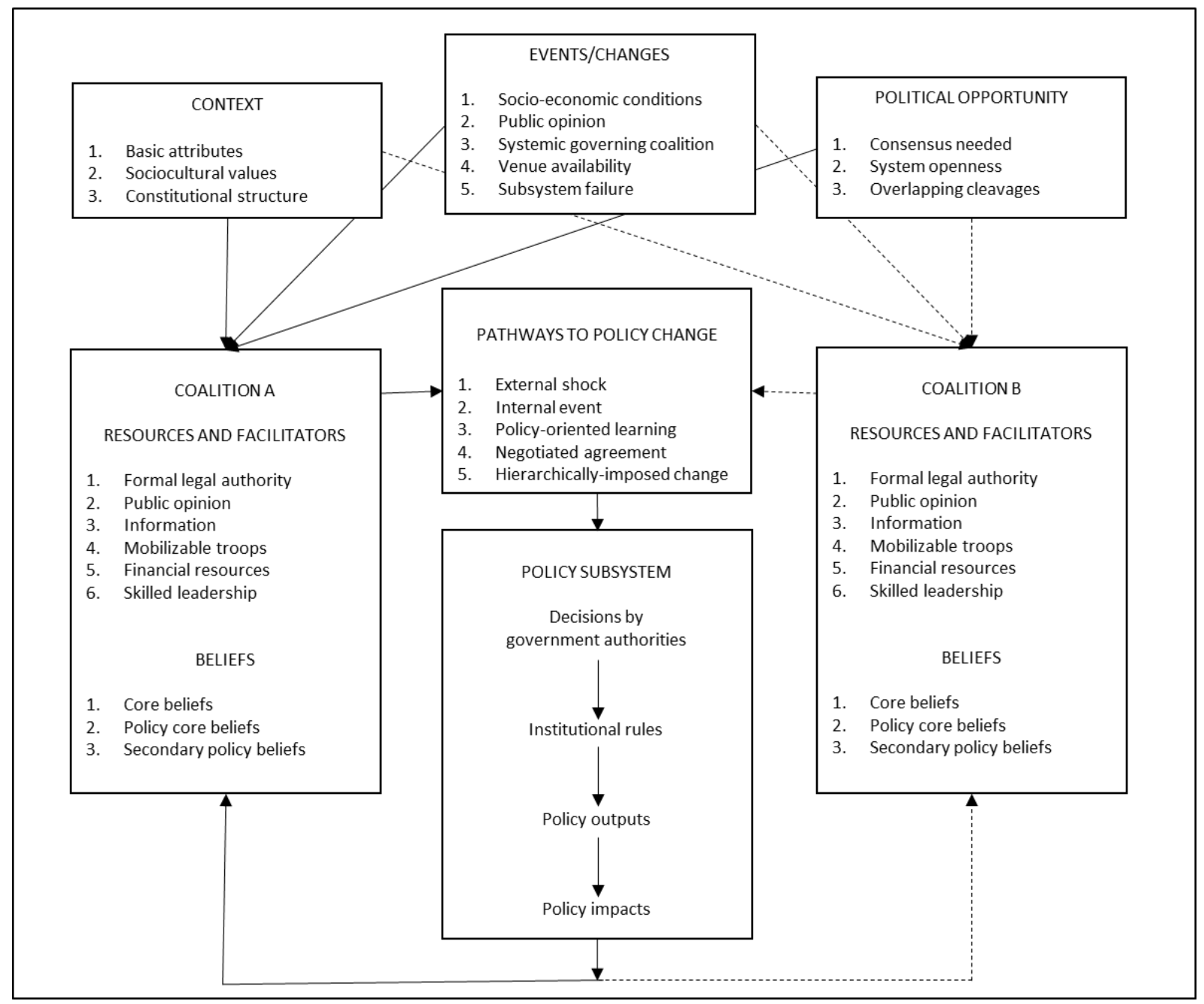

Figure 2: The Advocacy Coalition Framework, adapted from Jenkins-Smith et al. (2017)

\subsection{Alignment between the ACF and the Systems Change Model}

The ACF's approach is aligned with the Systems Change model's actor-driven model, which emphasizes the importance of values, "key players” and relationships (Hall et al., 2007) as key contextual and facilitating factors. The ACF also accommodates important strategies highlighted by the Systems Change model, including information diffusion and other communication efforts. Moreover, the ACF accommodates many of the concepts identified by previous disability-focused policy research, including strategic behavior by organized interests and the use of framing and narrative strategies to achieve policy goals. Finally, the ACF explicitly acknowledges both the role and intentions of researchers in the process of policy 
change (Sabatier and Weible, 2007), making the framework particularly appropriate, given the advocacy orientation of the Systems Change model.

\subsection{Sources of Change}

External or internal events are expected to increase the likelihood of policy change (Jenkins-Smith et al., 2017; Sabatier and Jenkins-Smith, 1993) External shocks, such as a socioeconomic change, a shift in public opinion, change to the governing coalition or change in another policy subsystem can function as such an event via heightened public and political attention, agenda change, redistribution of coalition resources and/or change to venue availability (Heikkila et al., 2014). Similarly, internal perturbations, such as a system failure or crisis, can also heighten attention to program deficiencies and reform opportunities (Jenkins-Smith et al., 2017). Finally, policy-oriented learning and negotiated agreement are alternative pathways to policy change (Jenkins-Smith et al., 2017). The Systems Change model, in contrast, places a strong emphasis on policy-oriented learning, but places little emphasis on the other pathways of change hypothesized by the ACF.

\subsection{Context}

The ACF also expects that “relatively stable parameters" (Jenkins-Smith et al., 2017; Sabatier and Jenkins-Smith, 1993), including basic attributes, sociocultural values, and constitutional structure may enhance (or detract) from the subsystem's conduciveness to policy change. The disability literature offers insight into subsystem attributes, as well as values and goals. For example, early research by McGaughey and Mank (2001a) shows that state-level ideology and economic conditions are predictors of integrated employment implementation. We might also expect overall welfare commitment to indicate a state's willingness and ability to support targeted services (Dilger and Boyd, 2014). There is also evidence that prior service investments and participation levels may influence the likelihood of change. McGaughey and Mank (2001a) find that a greater investment in supported employment are more likely to show higher levels of employment-related outcomes, which they attribute to state implementation “commitment."

The overall level of subsystem collaboration is also expected to influence the use of expert-based information and learning, with collaborative subsystems less likely to use expertbased information for political purposes than more adversarial subsystems (Weible, 2008). 
Collaboration and partnership have been key elements in the Systems Change model since its development (Hall et al., 2007), and Butterworth et al. (2017) identify interagency collaboration as a key predictor of positive change in employment outcomes.

\subsection{Political Opportunity}

Long-term political opportunity structures are more typically associated with variation in macro-political structures, more often observed at the international level. In this subsystem, we do not expect to see major differences in the opportunity structures typically highlighted by the ACF. However, variation in the decentralization of authority between state and local control may be expected to make a difference (Kübler, 2001). Indeed, the Systems Change model proposes that local control of service contracts (often at the county level) is more likely to yield positive changes to employment outcomes (Hall et al., 2007), suggesting that local authority increases political opportunities for policy change. On the other hand, low service provider capacity and competition, especially in rural areas (Van Slyke, 2007), might reduce the local policymakers' willingness and capacity to influence policy change.

\subsection{Resource Availability and Use}

The ACF further suggests that coalitions strategically use available resources and related strategies to influence decisions by government authorities, institutional rules, and ultimately, policy outputs and outcomes. Resources and related strategies can include formal legal authority, public opinion, information, mobilizable troops, financial resources and skilled leadership (Sabatier and Weible, 2007). The causal mechanisms by which an event leads to policy change include heightened public and political attention, agenda change, redistribution of resources and opening/closing of policy venues (Jenkins-Smith et al., 2017: 145; Nohrstedt, 2011).

Sabatier and Weible (2007) note that formal legal authority is a particularly effective coalition resource, and that coalitions often pursue related strategies, such as lobbying government officials and placing allies into positions of power, to increase the likelihood of achieving their policy preferences. Public opinion can serve to help sway decisions by officials in positions of authority, and coalitions typically invest heavily in efforts to gain the support of the public (Sabatier and Weible, 2007). However, in low salience policy subsystems like the DH\&E subsystems, we might expect public opinion to play a less important resource role (Jones and Jenkins-Smith, 2009). 
Relatedly, information is a key resource that can take multiple forms, including relatively neutral forms of information- and data-sharing, as well as more politicized use of framing and narrative strategies for persuasion purposes (Sabatier and Weible, 2007). Indeed, goal communication and training are both key methods of information-sharing in the Systems Change model (Hall et al., 2007). Researchers are included as potential policy actors by the ACF because of the potential role that researchers play in the information production and dissemination process (Sabatier and Weible, 2007). Given the goal-oriented nature of disability-focused research, we might expect disability researchers to play an important role in policy change.

Sabatier and Weible (2007) describe 'mobilizable troops' as an inexpensive resource often used by coalitions with few financial resources. Relatedly, Hall et al. (2007) highlight the importance of 'relationships' between policy actors to promote and support systems change. Moreover, Butterworth et al. (2017) acknowledges the importance of family members in key service-related decisions, which places them in the category of mobilizable troops. The federallyfinanced Protection and Advocacy (P\&A) system establishes a formal state-level network of advocacy channels.

Finally, 'skillful leadership’ (Sabatier and Weible, 2007) by ‘key players’ (Hall et al., 2007) is a key coalition resource for developing a vision, attracting resources, and using resources strategically. Relatedly, federal "anchoring” agencies can be an important source of leadership and belief system maintenance (Ellison and Newmark, 2010). A number of recent federal actions suggest renewed federal prioritization of CIE-focused services. For example, the 1999 Olmstead vs. L.C. U.S. Supreme Court decision and related Department of Justice litigation in two states (U.S. Department of Justice, Civil Rights Division, n.d.), the 2014 Medicaid "settings rule," (Centers for Medicare \& Medicaid Services (CMS), 2016) and multiple federal agency initiatives (e.g., U.S. Department of Health and Human Services, Administration on Community Living, n.d.; U.S. Department of Labor, n.d.a.) all point to a shift in federal priorities. And yet, some federal regulations that are arguably contrary to CIE priorities remain in place, such as the 1938 Fair Labor Standards Act that allows sub-minimum wage payments for individuals with disability (U.S. Department of Labor, n.d.b.). As such, we might expect to see national partners serving as a coalition resource. ${ }^{4}$

\footnotetext{
${ }^{4}$ The ACF acknowledges the possibility of nested subsystems (Weible and Sabatier 2014) but offers few examples or a prescription for treatment. This study recognizes that states are subject to federal government changes,
} 


\subsection{Methods}

This study takes a qualitative approach to addressing the research questions of interest, including: 1) What does state-level CIE-focused policy change look like? 2) Why and how did CIE-focused policy change occur? and 3) Why did states vary in the timing of policy change? The study uses multiple sources of data from two states (Washington and Pennsylvania) and a comparative analytic approach in the context of the ACF. This section describes the approach to ACF operationalization, as well as the case selection, data collection, coding and analysis methods.

\subsection{ACF Operationalization}

As Jenkins-Smith et al. (2014) acknowledge, the ACF offers an opportunity for contextualization and adaptation. This study uses three distinctive elements of ACF application, including subsystem delineation, definition of policy change, and identification and characterization of advocacy coalitions, to achieve a context-specific ACF operationalization. Sabatier (1988) defines the policy subsystem as the interaction between "non-trivial” policy actors who maintain an interest in a specific policy area. In this study, the subsystem is delineated as the DH\&E system in each state, from which relevant policy actors are expected to include (at a minimum) representatives from government agencies, politicians, advocacy organizations, service providers and professional associations.

Major policy changes include "significant shifts in the direction or goals of the subsystem” (Jenkins-Smith et al., 2017: 145), while minor policy changes primarily reflect a change in the means of achieving acknowledged goals (Jenkins-Smith et al., 2017; Sabatier and Jenkins-Smith, 1999). However, the study contextualizes that classification for this subsystem, such that major policy changes include those that impose restrictions on the status quo. Policies that supplement the status quo are categorized as minor change because the policies function predominantly as a means of achieving a previously stated goal.

Evidence for subsystem advocacy coalitions relies on findings from Giordono (2019), who uses a mixed method approach to identify the presence of two advocacy coalitions in each subsystem, called "Employment First” and “Choice,” which exhibit distinct policy core beliefs

influence from other national actors and that states learn from other states. However, the study also assumes that states have independent authority to plan, negotiate and make decisions according to state-level conditions. 
and policy preferences. The Employment First coalition would like to prioritize CIE-focused services and supports and minimize reliance on non-CIE services and supports. In contrast, the Choice coalition prefers to maintain a full range of options and allow individuals (and their families) to select the services and supports that best meet their needs. The Choice coalition tends to be loosely organized and reactive and has formally emerged in the early- to mid-2010s, even though it represents the status quo, while the Employment First coalition is well organized and pro-active.

Four main conceptual elements in the ACF include 1) event(s); 2) context; 3) political opportunity; and 4) coalition resource availability and use. As shown in Table 1, each conceptual element includes multiple conditions and sources of evidence, which were used to inform data collection, coding and analysis methods.

Table 1: Concepts, Conditions and Evidence

\begin{tabular}{|c|c|c|}
\hline Conceptual & Condition & Source of Evidence \\
\hline \multirow{9}{*}{ 递 } & Change in socio-economic conditions & $\begin{array}{l}\text { Overall unemployment } \\
\text { Overall labor force participation }\end{array}$ \\
\hline & Change in target population attributes & $\begin{array}{l}\text { Target population acuity } \\
\text { Target population diagnoses }\end{array}$ \\
\hline & Change in public opinion & $\begin{array}{l}\text { Media attention } \\
\text { Survey results }\end{array}$ \\
\hline & Change in systematic governing control & $\begin{array}{l}\text { Administrative leadership } \\
\text { Ideological/political divisions }\end{array}$ \\
\hline & Change in venue availability & $\begin{array}{l}\text { Lawsuit decision(s) } \\
\text { Legislation introduced } \\
\text { Administrative rule changes }\end{array}$ \\
\hline & Subsystem breakdown & $\begin{array}{l}\text { Hurting stalemate } \\
\text { Subsystem scandal(s) or crises }\end{array}$ \\
\hline & Change in overlapping subsystem & $\begin{array}{l}\text { Education policy } \\
\text { Vocational rehabilitation policy }\end{array}$ \\
\hline & Change in parallel subsystem & Other state policy \\
\hline & Hierarchical change & $\begin{array}{l}\text { Federal rules } \\
\text { Federal legislation } \\
\text { Federal judicial decision(s) }\end{array}$ \\
\hline \multirow{5}{*}{ 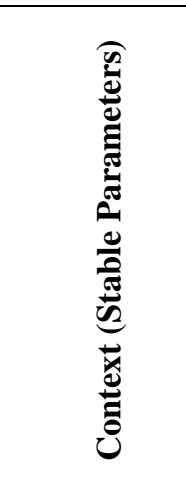 } & State political conditions & $\begin{array}{l}\text { Social welfare generosity } \\
\text { Citizen ideology } \\
\text { Government ideology }\end{array}$ \\
\hline & State economic conditions & $\begin{array}{l}\text { Overall unemployment } \\
\text { Overall labor force participation }\end{array}$ \\
\hline & Subsystem target population & Individuals with I/DD \\
\hline & Subsystem service history & $\begin{array}{l}\text { Prior CIE participation } \\
\text { HCBS access to services } \\
\text { County-based services }\end{array}$ \\
\hline & Subsystem service structures & $\begin{array}{l}\text { Use of managed care } \\
\text { Unionization of HCBS services } \\
\text { Service fragmentation }\end{array}$ \\
\hline
\end{tabular}




\begin{tabular}{|c|c|c|}
\hline \multirow{5}{*}{ 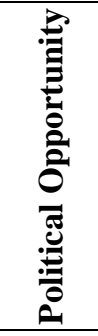 } & Degree of consensus required & Consensual decision rules (macro) \\
\hline & $\begin{array}{l}\text { System openness - } \\
\text { Venue structure }\end{array}$ & $\begin{array}{l}\text { Number of decision-making venues } \\
\text { Access to decision-making venues }\end{array}$ \\
\hline & $\begin{array}{l}\text { System openness - } \\
\text { Access to input and feedback opportunities }\end{array}$ & $\begin{array}{l}\text { Advocacy channels and networks } \\
\text { Public comment opportunities }\end{array}$ \\
\hline & $\begin{array}{l}\text { System openness - } \\
\text { Centralization of authority }\end{array}$ & Decentralized authority \\
\hline & Overlapping cleavages & Rural/urban and ideological divides \\
\hline \multirow{6}{*}{ 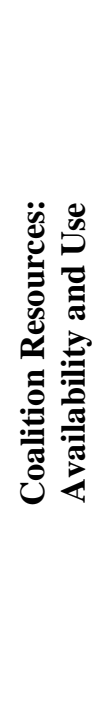 } & Formal legal authority & $\begin{array}{l}\text { Appointments } \\
\text { Lobbying campaigns }\end{array}$ \\
\hline & Public and political opinion & $\begin{array}{l}\text { Public and political attention } \\
\text { Public and political attitudes }\end{array}$ \\
\hline & Information & $\begin{array}{l}\text { Access to administrative data } \\
\text { Access to anecdotes/stories } \\
\text { Framing/narrative }\end{array}$ \\
\hline & Mobilizable troops & $\begin{array}{l}\text { Dedicated members/followers } \\
\text { Supply of and access to new recruits }\end{array}$ \\
\hline & Financial resources & $\begin{array}{l}\text { Private and public funding } \\
\text { Dedicated organization }\end{array}$ \\
\hline & Skilled leadership & $\begin{array}{l}\text { Experience and credibility } \\
\text { Skills and stability } \\
\text { Federal partnerships }\end{array}$ \\
\hline
\end{tabular}

\subsection{Case Selection and Data Collection}

The study uses a combination of telephone interview data and publicly available documents as the primary data sources. The two cases were selected purposively to maximize variation in the timing of policy adoption ${ }^{5}$ and policy-related outcomes ${ }^{6}$ during the study period (Gerring, 2008; Seawright and Gerring, 2008). In qualitative terms, Washington represents early adoption of CIE-focused policy (before 2014), while Pennsylvania is a late adopter (2014 or later). The semi-longitudinal nature of the study mitigates the threat to inference through "selection on the dependent variable” (King, 1994). Because both states ultimately experience major policy change, the design allows for a counterfactual based on the distinct timing of policy change. The sampling frame is provided in Appendix A1.

Using subsystem delineation parameters, an iterative search strategy was used to identify “non-trivial” policy actors. For each state, systematic a systematic Google search provided an

\footnotetext{
${ }^{5}$ For sampling purposes, policy adoption was limited to Executive Order and/or Legislation.

${ }^{6}$ Policy-related outcomes included the 1999 proportion of participants receiving supported employment services and the percentage change in that proportion from 1999-2014.
} 
initial source of policy-relevant sources, including organization websites, policy documents and news articles. ${ }^{7}$ The top 100 returns from each search were downloaded and screened for relevance. Databases for organizations and documents were produced from the search results. Organizational websites were screened for relevant documents and added to the document database, which was coded for stakeholder names, organizations and stakeholder type. All relevant results were entered into a respondent database. Policy actors with the highest citation frequencies from each stakeholder type were selected for initial contact. During the interview process, the respondent sample was supplemented by snowball sampling based on references provided by stakeholders (Lofland, 2006). A total of thirty-four semi-guided telephone interviews were conducted in the two states (20 in Washington; 16 in Pennsylvania). ${ }^{8}$ The completion rate among individuals who responded to the initial e-mail invitation was 80 percent in Washington and 61 percent in Pennsylvania. Interview respondents were assured anonymity to promote candid responses. The average interview duration was 50 minutes. See Appendices A2 and A3 for the interview guide and number of responses by stakeholder type. All interviews were recorded and transcribed.

Supporting data were retrieved from a variety of publicly available secondary sources. Selected documents from the initial Google search were catalogued for analytic use. In addition, LexisNexis searches were conducted to retrieve relevant items from state newspapers, yielding a total of 47 relevant items from 8 Washington newspaper and 101 items from 27 Pennsylvania newspapers. Targeted searches of state websites yielded official policy documentation, including legislation, executive orders and policy directives/memos. Documents relating to "Olmstead” cases were retrieved from the University of Michigan’s Civil Rights Litigation Clearinghouse

\footnotetext{
${ }^{7}$ The Google search included two iterations, including 1) an advanced Google search; and 2) a Google news search. The basic Google search used the following search terms: "[state name]" AND ("disability" OR "disabled" OR "intellectual disability" OR "intellectually disabled" OR "developmental disability" OR "developmentally disabled" OR "mentally retarded" OR "special needs") AND ("employment services" OR "sheltered workshop" OR "subminimum wage" OR "vocational rehabilitation" OR "supported employment" OR "integrated employment" OR "wage certificates" OR "employment first")); and 2) two Google News search using three combinations of search terms: a) [state name] AND "developmental disability" AND employment; b) [state name] AND "developmental disability" AND employment. Google searches were supplemented with documents provided by national telephone interview respondents. The Google news search used the following search terms in multiple iterations: [state name] AND ("developmental disability" OR "mental retardation") AND (employment OR sheltered workshop).

${ }^{8} \mathrm{An}$ additional 21 national-level respondents were identified and interviewed using similar respondent selection processes. Those responses were not included directly in this study, although data from those interviews for context and to interpret responses.
} 
(University of Michigan Law School, n.d.). Supporting documents transmitted by interview respondents were catalogued and reviewed. Extant state-level data related to demographics, socio-economic status, service participation and federal grant participation were gathered from a variety of sources, including the American Community Survey (U. S. Census Bureau, n.d.), StateData.info (University of Massachusetts Boston, Institute on Community Inclusion, n.d.), State of the States in Intellectual and Developmental Disabilities (Coleman Institute for Cognitive Disabilities at the University of Colorado, n.d.), State Fact Sheets (Center on Budget and Policy Priorities, 2012) and various federal government websites (e.g., U.S. Department of Labor, n.d.b.). Supplemental data were used as evidence for selected ACF conceptual elements, including 1) sources of change; 2) context; and 2) political opportunity.

\subsection{Coding}

All interview transcripts were coded in Dedoose 7 using ACF conceptual categories and a multi-staged coding strategy involving initial (open) coding on a sample of the interviews, followed by theoretically-grounded focused coding on all interviews (Lofland et al. 2006). The initial coding strategy was used to become familiar with the data and assess the relevance of ACF conceptual elements for the context and research questions of interest. A focused coding strategy was used to code each interview for the presence of selected ACF conceptual elements, including 1) external and system events; 2) coalition resource availability and use; 3) policy changes; and 4) beliefs and coalitions. See Appendix A4 for a detailed codebook, including primary codes and subcodes.

\subsection{Analytic Approach}

The coded and catalogued data were triangulated and used to inform within-case and cross-case comparative analyses. The within-case approach involved preparation of an in-depth case study for each case using theoretically-oriented process tracing methods to identify likely causal paths between one or more conditions and the outcome(s) of interest (George and Bennett, 2005). The results from the within-case analyses were then used comparatively, taking advantage of the longitudinal nature of the research design to yield inferences about the contributors to variation in policy change timing and pathways (George and Bennett, 2005).

\subsection{Case Summaries: Pennsylvania and Washington}


This section provides a brief overview of the events relating to CIE-focused policy change in Pennsylvania and Washington. Figure 4 shows a side-by-side visual of key events and policy changes in the two states between 1999 and 2017.

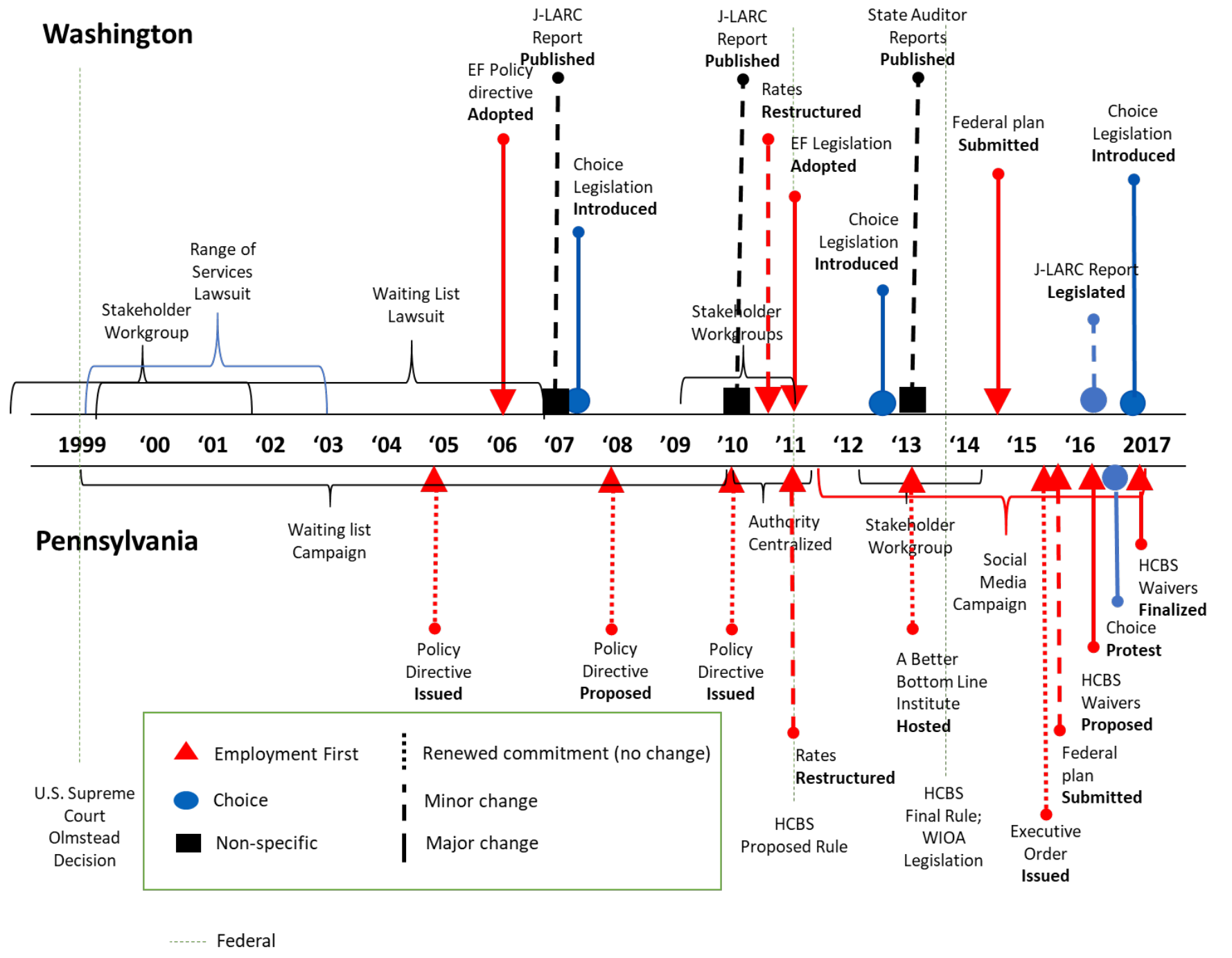

Figure 3: Timeline of Key Events and Policy Changes

\subsection{Washington}

In 2006, in the wake of a subsystem breakdown involving a legislated mandate to review system goals (Washington Legislature, 1998), Washington became one of the first adopters of a CIE-focused policy directive, the Working Age Adults Policy (Washington Department of Social and Health Services, 2004), which established employment supports as the first use of subsystem program funds for working-age adults (21 through 61 years) (Hall et al., 2007). The policy 
effectively displaced day habilitation (“community access”) services with CIE-focused services for the first nine months of service participation and was subsequently codified in 2012 legislation (Washington Senate, 2012). These efforts were followed by a 2015 commitment to eliminate new admissions to sheltered workshops as part of a HCBS transition plan (Washington State Department of Social and Health Services and Washington State Health Care Authority, 2015). The state also adopted several minor changes during the study period, including a comprehensive needs assessment strategy and outcomes-based service provider rates.

The Washington DH\&E has a strong history of employment-related service provision and stakeholder collaboration, but coalitions have become more active on both sides of the CIE policy issue, and the Choice coalition has repeatedly mobilized in response to Employment First policy changes and related activities. Respondents from both coalitions describe ongoing tension. One Choice respondent states:

If the jobs were available now, then Washington would already be an Employment First state. It's our position that Washington wants to become an 'Employment Only' state under the guise of 'Employment First'. (WA_ind30 telephone interview)

Similarly, an Employment First respondent describes ongoing discontent with the Employment First approach:

We've got some legislators who continue to oppose it. [Who] say, 'Why would we force people to try our most expensive service.'And we live that every year in legislation, and again, this year. So, even though we put Employment First in policy, now that policy is continually threatened... (WA_ind04 telephone interview)

\subsection{Pennsylvania}

Pennsylvania was slow to prioritize CIE-focused policy. Since 1990, Pennsylvania has had a written policy supporting access to employment opportunities for individuals with intellectual disability (Pennsylvania Department of Public Welfare, 1990), but service provision records suggest a low level of attention to integrated employment services. In 1999, only 19\% of Pennsylvania participants received integrated employment services, substantially lower than the average of 29\% among all states (University of Massachusetts Boston, Institute on Community Inclusion, n.d.). Moreover, no major policy changes occurred until after the 2014 HCBS Final Rule and related guidance, despite early attempts to renew the state's commitment to 
employment policies via policy directive in the 2000s. Increased attention to CIE-focused policies began in the early 2010s, with minor changes related to centralization of contracting authority and a related service provider rate restructuring process. After the federal "settings" rule was finalized, however, multiple changes occurred, including an Executive Order and new HCBS waiver rules that added new employment-focused service definitions and restricted facility-based participation.

Similar to Washington, Employment First coalition activity preceded major policy changes, beginning in the early 2010s with a stakeholder social media campaign and gubernatorial involvement in the "A Better Bottom Line" CIE-focused national campaign. The Choice coalition did not emerge until the new HCBS rules were announced in 2016. In response to the more restrictive rules, service providers, families and their legislators mobilized at a protest in Harrisburg, which led the state to reduce the restrictions. Employment First advocates have organized to promote Employment First legislation, which was introduced as HB 2130 in the 2015 session (Pennsylvania House of Representatives, 2015), introduced again as HB 1641 in the 2017 session (Pennsylvania Legislature, 2018). Respondents note that the legislation is intended to codify preceding policy changes, and that organizers have deliberately avoided including dramatic changes to sheltered workshop rules in the legislation. One Employment First supporter states:

I'll be absolutely frank in saying that we did not want to get into the middle of the sheltered workshop fight. We didn't think that was a fight that we could win... As much as we would like it to go further, we think there's only so much appetite politically that we can manage right now. (PA_ind51)

The legislation was ultimately signed into law by Governor Wolf in June 2018, with provisions for state agencies to prioritize supported employment services, establish a Governor's Cabinet for People with Disabilities and a goal for at least $7 \%$ of the state agency work force to comprised of individuals with disability (Pennsylvania Legislature, 2018).

\subsection{Findings}

Results from the study are organized around the three main research questions, including: 1) What does state-level CIE-focused policy change look like? 2) Why and how did CIE-focused policy change occur? and 3) Why did states vary in the timing of policy change?

\subsection{The Character of Policy Change}


In the context of the ACF policy changes include "significant shifts in the direction or goals of the subsystem” (Jenkins-Smith et al., 2017: 145), while minor policy changes include those that change only the means of achieving acknowledged goals (Jenkins-Smith et al., 2017; Sabatier and Jenkins-Smith, 1999). ${ }^{9}$ This study further refines the distinction, classifying "major” policy changes as those that impose restrictions on the status quo, and "minor" policy changes that simply provide continued support for the provision of CIE services without any accompanying change to non-CIE services. ${ }^{10}$ Washington and Pennsylvania both experienced major and minor policy changes over the course of the study period, but differed in the degree, timing and sequence, as shown in Table 2.

\footnotetext{
${ }^{9}$ In contrast, the Systems Change model does not distinguish between minor and major change.

${ }^{10}$ This distinction is derived from contextualization of the ACF. As such, the labels "major" and "minor" do not necessarily correlate with other assessments of policy change or importance (e.g., efficiency, effectiveness).
} 
Table 2: Comparison of Policy Changes

\begin{tabular}{|l|l|l|}
\hline & Washington & Pennsylvania \\
\hline Type of Change(s) & $\begin{array}{l}\text { Major changes: } \\
\text { 1) Working Age Adults Policy and } \\
\text { subsequent legislation } \\
\text { 2) Limits to sheltered workshop entry }\end{array}$ & $\begin{array}{l}\text { Major changes: } \\
\text { 1) Executive Order } \\
\text { 2) Community settings requirement } \\
\text { 3) Elimination of sub-minimum wage for } \\
\text { small group employment }\end{array}$ \\
& $\begin{array}{l}\text { Minor changes: } \\
\text { 1) Outcome-based rate structure } \\
\text { 2) Comprehensive needs assessment }\end{array}$ & $\begin{array}{l}\text { Minor changes } \\
\text { 1) New service definitions } \\
\text { 2) Outcome-based rate structure } \\
\text { 3) Certification requirements }\end{array}$ \\
\hline Timing & $\begin{array}{l}\text { Early (before 2014) and } \\
\text { Late (2014 or later) }\end{array}$ & $\begin{array}{l}\text { Late (2014 or later) } \\
\text { Sequence }\end{array}$ \\
& $\begin{array}{l}\text { Institutional rule-making } \\
\text { FOLLOWED BY } \\
\text { Decision by government authority } \\
\text { AND } \\
\text { Additional institutional rule-making }\end{array}$ & $\begin{array}{l}\text { Decision by government authority } \\
\text { FOLOWED BY } \\
\text { Institutional rule-making }\end{array}$ \\
\hline
\end{tabular}

\section{Types of Change}

Washington and Pennsylvania both made major policy changes during the study period. The Working Age Adults Policy in Washington clearly favors participation in employment services by placing limitations on participation in day habilitation services and stated limits to sheltered workshop entry forecloses on such services. In Pennsylvania, new waiver-related rules requiring at least $25 \%$ participation in a community setting also limits the use of segregated employment services. However, Washington changes are more restrictive to status quo service options and place a greater emphasis on employment.

These major policy changes might otherwise be described as incremental, in the sense of introducing marginal changes to existing rules. However, they clearly reflect a shift in the policy core beliefs, namely related to the importance and availability of traditional non-CIE services, and are described as meaningful by respondents. While the ACF does not preclude incremental change, major change is not typically described by ACF scholars in those terms.

Both states also made a variety of minor policy changes throughout the study period, such as new service definitions (Pennsylvania) and an outcomes-based rate structures (Washington and Pennsylvania), both of which reflect a shift in the means of encouraging participation in employment services. The Systems Change model explicitly anticipates these 
types of changes (e.g., flexible funding, incentive structures), but does not as clearly articulate the types of major changes observed in these subsystems.

\section{Timing and Sequence}

There are clear differences in the timing and sequence of policy changes. As expected, Washington experienced early major policy change (before 2014), while Pennsylvania did not experience major policy change until after 2014. In both states, the major policy changes are associated with a combination of decisions by government authorities and changes to institutional rules. The sequence of events differs in the two states, with policy directives and institutional rulemaking unexpectedly preceding decisions by government authorities in Washington state.

Furthermore, most of the changes might be best described as incremental, in the sense of introducing marginal changes to existing rules, despite being categorized as “major” changes and described as meaningful by respondents. While the ACF does not preclude incremental change, major change is not typically described by ACF scholars in those terms.

\subsection{Why and How Did Policy Change Occur?}

As shown in Figure 5, and described in the remainder of this section, the evidence suggests that in both cases, initial events and other key conditions yielded opportunities for Employment First supporters to proactively use coalition resources in pursuit of policy change. Choice supporters tended to act more reactively in response to the adoption and/or proposal of restrictive CIE-focused policies. See also Appendix A5 for a more detailed account of conditions in each state and time period. 


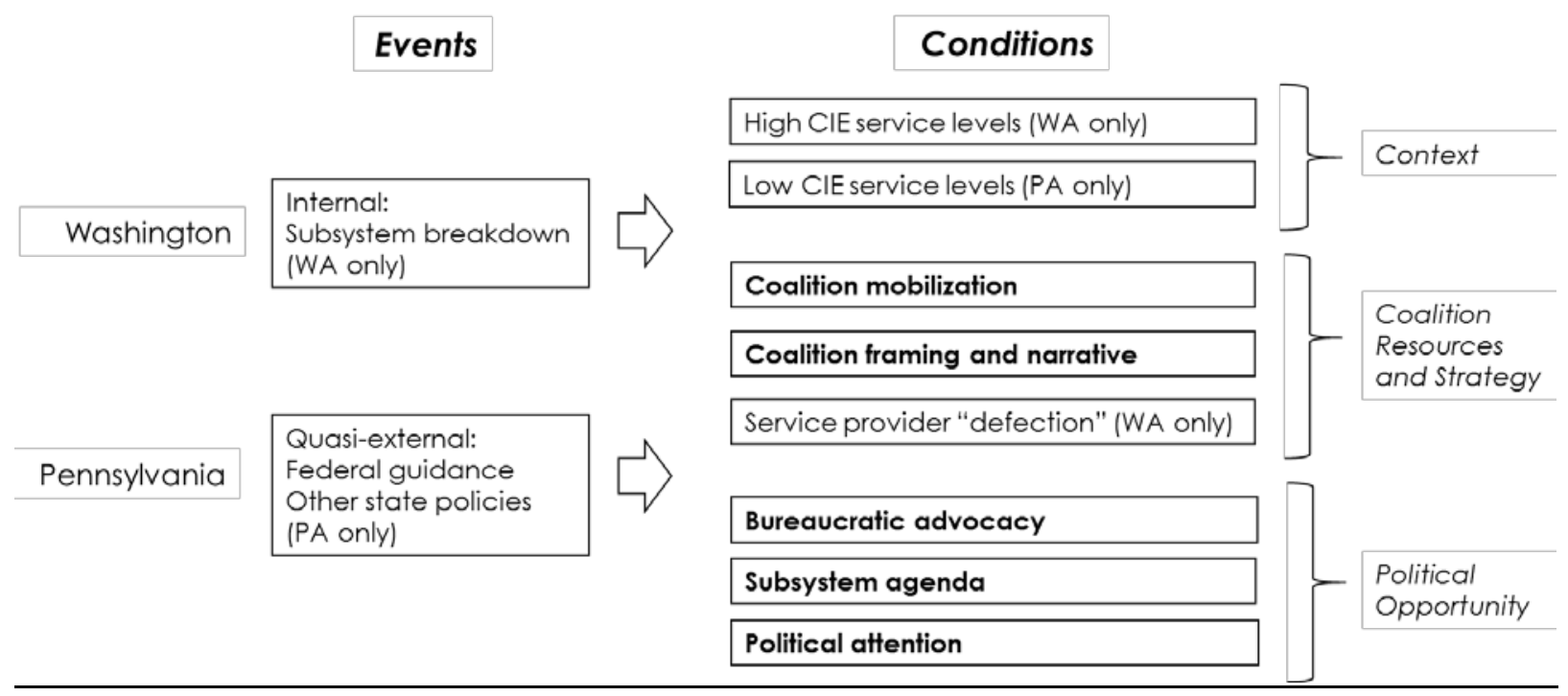

Figure 5: Conditions Associated With Change

Sources of Change

The ACF posits that multiple conditions can act as necessary, but not sufficient, sources of policy change. In both states, subsystem conditions provided the spark for subsequent coalition-based activity and policy change. In Washington, the late 1990s subsystem breakdown heightened political and subsystem attention to CIE-related issues and was closely followed by the (mandated) 2002 Stakeholder Workgroup report that articulated support for a Pathway to Employment, as well as the 2003 dismissal of the Arc of Washington vs. Quasim lawsuit that argued for a full range of services (University of Michigan Law School, n.d.). The later events represented a negotiated agreement and a judicial venue closure, respectively, offering an opportunity for administrative leadership to formulate and implement the initial Working-Age Adult Policy. Pennsylvania also experienced subsystem breakdowns in the 2000s, but the resulting subsystem and political attention targeted waitlist issues and problems with the countybased contracting, rather than the service mix. ${ }^{11}$ However, the 2014 federal HCBS "settings” rule served as a primary motivator for major policy changes in both states. In Pennsylvania, observations of Olmstead-related litigation in other states also provided an impetus for change. These observations suggest that Washington experienced an internal pathway to policy change, while Pennsylvania experienced a quasi-external pathway.

\footnotetext{
${ }^{11}$ In Washington, issues related to the waitlist were resolved in the judicial venue.
} 
However, there is also evidence that policy-oriented learning contributed to minor policy changes in both Pennsylvania and Washington. The process of developing a comprehensive needs assessment process (WA) and setting outcomes-based rate structures (both PA and WA) were both accompanied by substantial reference to research and extant data. There is less evidence of policy-oriented learning before the major changes, as indicated by technical analysis and related analytic debate. However, selected service providers in Washington refer to survey data (showing that individuals would prefer to work) as an instigator for subsequent efforts to transform their service structures.

\section{$\underline{\text { Context, Political Opportunity and Coalition Resources/Strategies }}$}

Relatively stable state and subsystem contextual attributes can also influence the favorability of the environment to policy change. The two states experience only slight differences in political climate and key economic conditions. Washington's government is historically more liberal, although the two states are equivalent with respect to citizen ideology (Fording, 2018). Economic conditions, including unemployment and labor force participation responses to the Great Recession, were similar during the study period (US Census Bureau n.d.). Moreover, subsystem service structures were similar - both states relied on fee-for-service models (i.e., not managed care) and HCBS services were not unionized in either state. Finally, despite differences in government ideology, the states’ overall welfare commitment, including TANF participation and support and Medicaid expansion, has followed similar trends over time.

However, the two states’ portfolio of CIE-focused service provision prior to the study period was dramatically different. In Washington, the proportion of participants receiving integrated employment services in 1999 was 58\%, compared with only 19\% of Pennsylvania participants. Furthermore, the proportion grew to 85\% in Washington, while Pennsylvania’s proportion remained consistently low. It is challenging to disentangle the influence of service levels from other conditions. However, there is little evidence that service levels alone influence policy; instead, they interact with coalition resources and strategies to yield a pathway to policy change. The evidence in this study suggests that service levels matter, in these cases, at least in part because of the influence on coalition membership, especially among service providers.

Service providers advocate for policy change on their own behalf and can also act as mobilizers of families and individuals. In the late 1990s, major Washington service providers formed an advocacy network (P2000, subsequently renamed P2020) separate from the traditional 
service provider association Rehabilitation Enterprises of Washington (REW). In the 2000s, P2020 and REW merged to form the Community Employment Alliance and issued a statement declaring CIE as its preferred policy and yielding an important source of support for proposed policy changes. In contrast, service providers in Pennsylvania played an active role in mobilizing individuals and families against proposed rule changes, suggesting that service provider coalition membership plays an important causal link between service levels and policy change.

Since the finalization of the 2014 federal HCBS rule, however, most service providers (and their professional associations) in both states anticipate eventual implementation of federal regulations, and articulate some combination of support, neutrality, or resignation toward Employment First policy positions. One representative from a Pennsylvania professional association states “The state's really careful to say they're not mandating closure of these workshops or adult training facilities, but the landscape is really changing” (PA_ind45 telephone interview). That said, in both states, a contingent of service providers have mobilized against CIE-focused policy in the form of Choice coalitions, and in Pennsylvania there is little of a mass coalition defection by service providers similar to that experienced in Washington in the 2000s.

Political opportunity refers to the influence of long-term opportunity structures and political environment on the resources and behaviors of subsystem actors and coalitions (Sabatier and Weible, 2007). In these cases, bureaucratic advocacy stands out as a key contributing factor related to policy change in both states. Major CIE-focused policy change in both states was initially achieved via policy directive (in Washington) and rulemaking (in Pennsylvania) by administrative leaders widely recognized as vocal and skilled Employment First champions. These findings are aligned with both ACF suggestions that formal legal authority is one of the most powerful coalition resources (Sabatier and Weible, 2007), as well as with literature acknowledging the active role of bureaucrats in the policymaking process (Krause, 1999; Workman, 2015). That said, an attempted CIE-focused change via policy directive in Pennsylvania during the late 2000s failed, suggesting that bureaucratic advocacy alone is not sufficient for policy change, but also requires strong and committed administrative leadership.

The contribution of decentralized authority (to the county level) is unclear, although multiple respondents attributed Washington policy changes to county authority. However, authority in Pennsylvania was similarly decentralized during the same period, and no change 
occurred there, even under the leadership of a sympathetic state administrator. Moreover, by the time that Pennsylvania began to explore policy change, authority had been centralized at the state level, in response to federal concerns about inconsistent county contracting practices. These findings suggest that goal alignment between state and county administrations offered the opportunity and support for change, rather than the structure itself.

There is little evidence that macro-level long-term opportunity structures influenced policy change. As US states, both subsystems are pluralist subsystems with concomitant high consensus requirements and formal system openness. Moreover, both states are subject to overlapping rural/urban and ideological divides, suggesting that such cleavages do not explain observed differences in the policy process, although there is some evidence that such cleavages may contribute to coalitional divergence in policy preferences. However, it would be illconsidered to deny the influence of the national stage on state-level choices, even though national events, support and guidance are broadly applicable to all states. National events and support offered opportunities for policy actors, especially those from the Employment First coalitions, to raise the profile of CIE-focused policy change on the subsystem agenda and to provide a coalition-based interpretation. Furthermore, stakeholders in both states have access to the formal, federally-supported Protection and Advocacy system, and there is evidence that the P\&A-supported organizations (e.g., DD Council, Disability Rights Network, UCEDD) are active in both states. Similarly, there is strong evidence of both formal channels of communication and advocacy (e.g., public comment periods) in both states, as well as informal networks. However, there is some evidence that the Employment First coalition in Washington had closer ties with national supporters in the 2000s, while Pennsylvania ties with national supporters were relatively weak until the mid-2010s.

In both states, the Employment First coalition was more proactive in its pursuit of major policy change, while the Choice coalition tended to mobilize more reactively in response to proposed or actual policy changes. The character of mobilization in both states suggests that the Employment First coalition has access to more resources than the Choice coalition, especially during the period(s) prior to policy change. However, both coalitions attempted to influence policy via heightened political and subsystem attention, especially through the strategic connections to allies in positions of authority, information, and mobilizable troops. 
The Employment First coalition maintained a strong connection in the form of an ally in agency leadership in both states. In Washington, for example, while respondents noted the important contributions of skilled advocacy leadership, a dedicated organization (WISE) and county-based support, they attributed the initial policy directive to the Director of Developmental Disabilities Division Linda Rolfe, who held that position until 2013. Similarly, Deputy Secretary Nancy Thaler in Pennsylvania has been given much of the credit for recent changes in Pennsylvania, although respondents also noted the contributions of her predecessor Steve Suroviec and other advocacy leaders. In contrast, the Choice coalition does not appear to have had formal support among state agency leadership, instead focusing on establishing connections with legislative allies, often relying on existing advocacy channels and frequent in-person contact. The Employment First coalition also invested in establishing and maintaining relationships with state legislators to influence CIE-focused policy change.

Relatedly, both coalitions strategically used information and mobilizable troops in tandem in both states. For example, the Pennsylvania Choice coalition relied heavily on these strategies, mobilizing sheltered workshop participants and their families to protest proposed rule changes at the Capitol, providing insight into the path dependent nature of subsystem policy change and stasis. Similarly, the Employment First coalition in Pennsylvania mobilized individuals with I/DD to develop a social media campaign (\#iwanttowork) that respondents attribute with focusing political attention on CIE-focused policy. The coalitions typically rely on civil rights framing (employment as a right, choice as a right) and narrative (stories of hope, stories of decline), targeting subsystem stakeholders and selected government authorities, to influence major policy change. In Washington, administrative data has also been used by both coalitions since the initial policy change, both politically and instrumentally. Thus far, Pennsylvania coalitions show little evidence of using administrative data to influence major policy change, relying more heavily on framing to convey information. In contrast, administrative data and expert-based opinion were used in both states to influence minor changes, as anticipated by the ACF. Interestingly, neither coalition in either state focused its resources on influencing broader public opinion.

\subsection{Why did states vary in the timing of policy change?}

Again returning to Figure 2, several distinguishing subsystem conditions stand out as having an influence on the timing of major policy change. First, as was previously 
acknowledged, the two subsystems faced very different initial service levels. Second, the mass defection of service providers from the Choice coalition in Washington, as indicated by reform of the main professional association, signaled support for major policy change from that stakeholder group. While service providers in Pennsylvania are cognizant of the federal changes, they have not publicly announced a preference for Employment First policy en masse. While they are not necessarily opposed to all Employment First policy, they are protective of traditional services and mobilize as necessary to resist reform.

Second, the waiting list issue emerged as a major issue in both states in the early 2000s. In Pennsylvania, advocates formulated a major mobilization campaign to address the issue with direct advocacy. In contrast, Washington waiting list issues were addressed by the judicial system, freeing up stakeholders to pursue CIE-related issues. These observations suggest that in a system with limited resources, competing subsystem agenda items can also influence the timing of policy change.

Finally, even though the study timeframe extended only to 1999, multiple Washington respondents stated without prompting that policy decisions made in the 1980s and 1990s were integral to the policy changes that occurred in the 2000s. One respondent states, for example: "I think the only other unique thing is just, and I'm biased of course, is just that Washington has invested so strongly in training and TA for the last 30 years... that's one key piece of their success over the years" (WA_ind01, telephone interview August 2017). While this observation is aligned with those made by disability researchers (e.g., Hall et al., 2003, 2007; Winsor et al., 2006), neither the Systems Change framework nor the ACF provides a strong causal mechanism for linking previous policy decisions, especially minor ones, to subsequent policy change. That said, we might hypothesize a relationship between these decisions, which heavily targeted service providers, subsequent service levels and the service provider coalition defection observed in the 2000s.

\subsection{Discussion and Conclusion}

From a policy perspective, considerable federal government resources invested in prioritizing competitive, integrated employment outcomes for individuals with I/DD and highlights the promise of policy instruments for outcome achievement. And yet, we continue to see variation in state-level policy change timing and content. Shining a spotlight on the policy process helps refine our understanding of the types of policy change (minor and major) and 
conditions that are conducive to major policy change. Moreover, modeling policy change as a coalition-based competition provides information about conditions under which major policy change is likely to occur, as well as likely responses to policy change.

This study offers insight into conditions conducive to state-level policy change that are expected to be useful to both policymakers and researchers. While some of these findings are unlikely to come as a surprise to DH\&E stakeholders, the findings are likely to offer insight into an ongoing nationwide change process. This application points to a number of coalition-based strategies and resources that have the potential to accelerate or inhibit change. Moreover, application highlights the potential conflicts that arise in the context of major policy change. Changes to rate structures and assessment tools are not "major" changes (as defined by the ACF, in the sense of changing belief systems) but may still be effective and meaningful for achieving policy goals related to employment outcomes without introducing conflict. In a system that prides itself on collaboration and trust, reformers may need to weigh the costs and benefits of pursuing major change. Finally, the ACF shines light on the implications of the subsystem agenda and attention for policy change; limited stakeholder attention and capacity means that strategic decisions about priority issue areas matter. In a small, mobilization-reliant subsystem like DH\&E, choosing to prioritize gains in one area (e.g., waitlist) may come at the expense of gains in another area (e.g., CIE policy).

This study also offers several contributions to the policy process literatures with respect to both application and theory development. First, it extends application of the ACF to a low salience setting, substantiating several core ACF hypotheses related to policy change and coalitional activity, and illustrating common pathways to major policy change. Furthermore, several of the highlighted conditions, including bureaucratic advocacy, stakeholder mobilization and use of information, and heightened political attention, tell a story of change at the margins of public attention, which is aligned with Krause's (1999) and Workman's (2015) models of a dynamic role for bureaucrats. The study also substantiates Jones and Jenkins-Smith's (2009) hypotheses that coalitions in low salience subsystems are less likely to rely on public opinion as a resource for pursuing policy change.

That said, there are limitations to what can be inferred from the study findings. First, the overall research design limits causal inference. Although the findings are likely to be analytically generalizable, findings from a two-case study are not generalizable to the larger population of 
US states, especially given the possibility of other pathways to change (e.g., hierarchical imposition). Furthermore, despite the use of variation in policy change timing as a counterfactual, the two cases selected for inclusion did not include any states that had not experienced policy change. The sample of respondents is small and non-representative and the sources of external information (e.g., media and policy documentation) are limited, although the study triangulates data from multiple sources wherever possible.

Looking forward, there are opportunities for the findings from this study to contribute to future applied and scholarly research. The Systems Change model, for example, is used as the basis for decision-making and technical assistance in a variety of government initiatives (e.g., Butterworth et al., 2017). While this study does not explicitly recommend changes to that model, it offers insights into categories of policy change and the influence of a variety of political factors on policy change. For example, the Systems Change model could be revised to more explicitly highlight the strategic activities of bureaucrats, service providers and other stakeholders. The causal mechanisms articulated by the Systems Change model also overlook the role of coalition-based activity. More explicit acknowledgment of coalitional differences and related strategies is likely to yield a more transparent and inclusive model of change.

The study also highlights opportunities to refine the ACF, which tends to treat policy change as dichotomous (minor/major) and focuses heavily on "dramatic and nonincremental” change (Jenkins-Smith et al., 2014: 201). In contrast, this study reveals a more complex process involving a sequence of major policy change that occur in multiple forms (e.g., policy directive and legislation) and at multiple timepoints, as well as coexisting minor and major policy changes. Moreover, this study highlights a potential connection between pre-1999 efforts to promote competitive, integrated employment, and subsequent changes in service provider coalition membership (i.e., defection) that are a main condition for early or late adoption. Indeed, Pierson (2004) describes a process of path dependence, by which relatively small events or decisions influence subsequent consequences due to increasing returns associated with the earlier decisions.

These observations suggest complexities in the policy change process that are not easily addressed by the ACF, and an opportunity for theoretical refinement. Streeck and Thelen (2005) identify a typology of gradual, transformative change that includes multiple types of institutional change, including layering, displacement, drift, conversion and exhaustion. There are parallels 
between these categories of change and those observed in this study. The minor policy changes, for example, resemble a process by which CIE-focused policy is "layered" onto the existing service mix without explicitly making changes to more traditional service options. The major policy changes, meanwhile, are similar to "displacement," whereby policy changes both enhance CIE service options and limit non-CIE options. Mahoney and Thelen (2009) take that work a step further with the development of the Theory of Gradual Institutional Change, which articulates theoretical connections between different types of change, including causal mechanisms that result in transition from one type of change to another. Extending the ACF with their Theory of Gradual, Institutional Change is likely to accommodate a more complex understanding of policy changes and offer a richer understanding of the policy change process in circumstances like those faced by the I/DD subsystems of Washington and Pennsylvania. 


\subsection{References}

Agranoff R (2013) The Transformation of Public Sector Intellectual/Developmental Disabilities Programming. Public Administration Review 73: S127-S138. DOI: 10.1111/puar.12101.

Berry FS and Berry WD (2017) Innovation and Diffusion Models in Policy Research. In: Weible CM and Sabatier P (eds) Theories of the Policy Process. Fourth edition. Boulder, CO: Westview Press, a member of the Persus Books Group.

Braddock D, Rizzolo MC and Hemp R (2004) Most employment services growth in developmental disabilities during 1988-2002 was in segregated settings. Mental Retardation 42(4): 317-320.

Butterworth J, Gilmore DS, Kiernan WE, et al. (1999) State Trends in Employment Services for People with Developmental Disabilities: Multiyear Comparisons Based on State MR/DD Agency and Vocational Rehabilitation (RSA) Data. June. Boston, MA: Institute for Community Inclusion, University of Massachusetts Boston.

Butterworth J, Cohen Hall A, Freeze S, et al. (2008) State Employment Practices: Funding for Employment Services. July. Institute for Community Inclusion, University of Massachusetts Boston. Available at: https://www.communityinclusion.org/pdf/all_D3.pdf (accessed 9 December 2015).

Butterworth J, Smith FA, Winsor J, et al. (2016) StateData: The 2015 National Report on Employment Services and Outcomes. Institute for Community Inclusion, University of Massachusetts Boston. Available at: http://www.statedata.info/sites/statedata.info/files/files/statedatabook_2015_F.pdf (accessed 12 August 2016).

Butterworth J, Christensen J and Flippo K (2017) Partnerships in Employment: Building strong coalitions to facilitate systems change for youth and young adults. Journal of Vocational Rehabilitation 47(3): 265-276. DOI: 10.3233/JVR-170901.

Center on Budget and Policy Priorities (2012) State Fact Sheets: How States Have Spent Funds Under the TANF Block Grant. Available at: https://www.cbpp.org/research/family-income-support/statefact-sheets-how-states-have-spent-funds-under-the-tanf-block (accessed 26 October 2018).

Centers for Medicare \& Medicaid Services (CMS) (2016) Medicaid and CHIP Managed Care Final Rule (CMS 2390 -F). 25 April. Available at: https://www.medicaid.gov/medicaid-chip-programinformation/by-topics/delivery-systems/managed-care/downloads/strengthening-the-delivery-ofmanaged-long-term-services-and-supports-fact-sheet.pdf (accessed 14 July 2016).

Coleman Institute for Cognitive Disabilities at the University of Colorado (n.d.) State of the States in Intellectual and Developmental Disabilities. Available at: https://www.colemaninstitute.org/stateof-the-states-in-intellectual-and-developmental-disabilities/ (accessed 26 October 2018).

Dilger RJ and Boyd E (2014) Block Grants: Perspectives and Controversies. 15 July. Congressional Research Service. Available at: http://www.fas.org/sgp/crs/misc/R40486.pdf (accessed 7 December 2014).

Ellison BA and Newmark AJ (2010) Building the Reservoir to Nowhere: The Role of Agencies in Advocacy Coalitions. Policy Studies Journal 38(4): 653-678. DOI: 10.1111/j.15410072.2010.00378.x.

Fording RC (2018) State Ideology Data. In: Richard C. Fording. Available at: https://rcfording.wordpress.com/state-ideology-data/ (accessed 1 August 2018). 
Friedman C (2016) Day Habilitation Services for People With Intellectual and Developmental Disabilities in Medicaid Home and Community-Based Services Waivers. Research \& Practice for Persons with Severe Disabilities 41(4): 244-255. DOI: 10.1177/1540796916664337.

George AL and Bennett A (2005) Case Studies and Theory Development in the Social Sciences. Fourth Printing edition. Cambridge, Mass: The MIT Press.

Gerring J (2008) Case Selection for Case Study Analysis: Qualitative and Quantitative Techniques. In: Box-Steffensmeier JM, Henry E. Brady, and Collier D (eds) The Oxford Handbook of Political Methodology. Oxford handbooks of political science. Oxford ; New York: Oxford University Press.

Gettings RM (2011) Forging a federal-state partnership : a history of federal developmental disabilities policy. American Association on Intellectual and Developmental Disabilities ; Alexandria, Va.

Giordono LS (2019) Advocacy Coalitions in Low Salience Policy Subsystems: Struggles Under a Smooth Surface. Policy Studies Journal 0(0). DOI: 10.1111/psj.12330.

Hall AC, Butterworth J, Gilmore DS, et al. (2003) High-Performing States in Integrated Employment. 32, Research to Practice, February. Institute for Community Inclusion, University of Massachusetts Boston. Available at: https://www.communityinclusion.org/article.php?article_id=121 (accessed 20 July 2018).

Hall AC, Butterworth J, Winsor J, et al. (2007) Pushing the employment agenda: case study research of high performing States in integrated employment. Intellectual and developmental disabilities 45(3): 182-98.

Hall AC, Freeze S, Butterworth J, et al. (2011) Employment funding for intellectual/developmental disability systems. Journal of Vocational Rehabilitation 34(1): 1-15.

Heikkila T, Pierce JJ, Gallaher S, et al. (2014) Understanding a Period of Policy Change: The Case of Hydraulic Fracturing Disclosure Policy in C olorado. Review of Policy Research 31(2): 65-87. DOI: $10.1111 /$ ropr.12058.

Inge KJ, Graham CW, Brooks-Lane N, et al. (2018) Defining customized employment as an evidencebased practice: The results of a focus group study. Journal of Vocational Rehabilitation 48(2): 155-166. DOI: 10.3233/JVR-180928.

Itkonen T (2007) Politics of Passion: Collective Action from Pain and Loss. American Journal of Education 113(4): 577-604. DOI: 10.1086/518489.

Itkonen T (2009) Stories of Hope and Decline Interest Group Effectiveness in National Special Education Policy. Educational Policy 23(1): 43-65. DOI: 10.1177/0895904808328526.

Jenkins-Smith H, Nohrstedt D, Weible CM, et al. (2014) The Advocacy Coalition Framework: Foundations, Evolution and Ongoing Research. In: Sabatier PA and Weible CM (eds) Theories of the Policy Process. Boulder, CO: Westview Press, pp. 183-224.

Jenkins-Smith H, Nohrstedt D, Weible CM, et al. (2017) The Advocacy Coalition Framework: An Overview of the Research Program. In: Weible CM and Sabatier PA (eds) Theories of the Policy Process. Boulder, CO: Westview Press, pp. 183-224.

Jeon Y and Haider-Markel DP (2001) Tracing Issue Definition and Policy Change: An Analysis of Disability Issue Images and Policy. Policy Studies Journal 29(2): 215. 
Jones MD and Jenkins-Smith HC (2009) Trans-Subsystem Dynamics: Policy Topography, Mass Opinion, and Policy Change. Policy Studies Journal 37(1): 37-58. DOI: 10.1111/j.1541-

0072.2008.00294.x.

Kiernan WE, Hoff D, Freeze S, et al. (2011) Employment first: a beginning not an end. Intellectual and developmental disabilities 49(4): 300-4. DOI: 10.1352/1934-9556-49.4.300.

King G (1994) Designing Social Inquiry: Scientific Inference in Qualitative Research. Princeton paperbacks. Princeton, New Jersey: Princeton University Press.

Krause GA (1999) A Two-Way Street: The Institutional Dynamics of the Modern Administrative State. Pittsburgh, Pa.: University of Pittsburgh Press.

Kübler D (2001) Understanding policy change with the advocacy coalition framework: an application to Swiss drug policy. Journal of European Public Policy 8(4): 623-641. DOI: 10.1080/13501760110064429.

LEAD Center (n.d.) Employment First webpage. Available at: http://drivedisabilityemployment.org/ (accessed 6 July 2018).

Lofland J (2006) Analyzing Social Settings: A Guide to Qualitative Observation and Analysis. 4th ed. Belmont, CA: Wadsworth/Thomson Learning.

Mahoney J and Thelen K (2009) Explaining Institutional Change: Ambiguity, Agency, and Power. Cambridge University Press.

Martinez K (2013) Integrated employment, EmploymentFirst, and U.S. federal policy. Journal of Vocational Rehabilitation 38(3): 165-168. DOI: 10.3233/JVR-130631.

Mcgaughey M and Mank D (2001a) Empirical Evidence of Systems Change in Supported Employment. Journal of Disability Policy Studies 11(4): 210-222. DOI: 10.1177/104420730101100403.

Mcgaughey M and Mank D (2001b) State policy innovation and systems change: the context for the supported employment initiative. Journal of Disability Policy Studies 11(4): 202-209. DOI: 10.1177/104420730101100402.

Nagel P (2006) Policy Games and Venue-Shopping: Working the Stakeholder Interface to Broker Policy Change in Rehabilitation Services. Australian Journal of Public Administration 65(4): 3-16. DOI: 10.1111/j.1467-8500.2006.00500a.x.

Niemiec B, Lavin D and Owens LA (2009) Establishing a National Employment First Agenda. Journal of Vocational Rehabilitation 31(3): 139-144. DOI: 10.3233/JVR-2009-0483.

Nohrstedt D (2011) Shifting Resources and Venues Producing Policy Change in Contested Subsystems: A Case Study of Swedish Signals Intelligence Policy. Policy Studies Journal 39(3): 461-484. DOI: 10.1111/j.1541-0072.2011.00417.x.

Nord D (2014) Employment First Across the Nation: Progress on the Policy Front. Policy Research Brief, 1 March. University of Minnesota, rtc on Community Living. Available at: http://rtc.umn.edu/prb/214/ (accessed 14 September 2015).

Nord D, Luecking R, Mank D, et al. (2013) The State of the Science of Employment and Economic SelfSufficiency for People With Intellectual and Developmental Disabilities. Intellectual and Developmental Disabilities 51(5): 376-384. DOI: 10.1352/1934-9556-51.5.376. 
Pennsylvania Department of Public Welfare (1990) MR Bulletin 6000-90-06. Policy on Employment for Persons with Mental Retardation. Available at:

https://www.temple.edu/thetrainingpartnership/resources/mrBulletins/misc/6000-90-06.pdf (accessed 6 February 2018).

Pennsylvania House of Representatives (2015) HB 2130. Employment First Act. Session of 2015.

Available at:

http://www.legis.state.pa.us/cfdocs/billinfo/billinfo.cfm?syear=2015\&sind=0\&body=H\&type=B

\&bn=2130 (accessed 19 October 2017).

Pennsylvania Legislature (2018) Act 36 (HB 1641). Employment First Act. Session of 2018. Available at: http://www.legis.state.pa.us/cfdocs/billinfo/billinfo.cfm?syear=2017\&sind=0\&body=H\&type=B \&bn=1641 (accessed 19 October 2017).

Pettinicchio D (2013) Strategic Action Fields and the Context of Political Entrepreneurship: How Disability Rights Became Part of the Policy Agenda. Research in Social Movements, Conflicts and Change 36: 79-106. DOI: 10.1108/S0163-786X(2013)0000036006.

Pierce JJ, Peterson HL, Jones MD, et al. (2017) There and Back Again: A Tale of the Advocacy Coalition Framework. Policy Studies Journal 45(S1): S13-S46. DOI: 10.1111/psj.12197.

Pierson P (2004) Politics in Time: History, Institutions, and Social Analysis. Princeton: Princeton University Press.

Racino JAR (2015) Public Administration and Disability: Community Services Administration in the U.S. Boca Raton: CRC Press, Taylor \& Francis Group.

Rogan P and Rinne S (2011) National Call for Organizational Change From Sheltered to Integrated Employment. Intellectual and Developmental Disabilities 49(4): 248-260. DOI: 10.1352/19349556-49.4.248.

Rogers EM (1995) Diffusion of Innovations. 4th ed. New York: Free Press.

Rusch FR and Braddock D (2004) Adult day programs versus supported employment (1988-2002): Spending and service practices of mental retardation and developmental disabilities state agencies. Research and Practice for Persons with Severe Disabilities 29(4): 237-242.

Sabatier PA (1988) An Advocacy Coalition Framework of Policy Change and the Role of PolicyOriented Learning Therein. Policy Sciences 21(2/3): 129-168.

Sabatier PA and Jenkins-Smith H (1999) The Advocacy Coalition Framework: An Assessment. In: Sabatier PA (ed.) Theories of the Policy Process. First edition. Boulder, CO: Westview Press, a member of the Persus Books Group, pp. 117-168.

Sabatier PA and Jenkins-Smith HC (1993) Policy Change and Learning : An Advocacy Coalition Approach. Theoretical lenses on public policy. Boulder, Colo: Westview Press.

Sabatier PA and Weible CM (2007) The Advocacy Coalition Framework: Innovations and Clarifications. In: Sabatier PA (ed.) Theories of the Policy Process. Second edition. Boulder, CO: Westview Press, a member of the Persus Books Group, pp. 189-222. Available at: http://200.41.82.27/108/1/Sabatier,\%20Paul,\%20Weible\%20C_The\%20Advocacy\%20Coalition \%20Framework.\%20Innovations\%20and.pdf (accessed 8 November 2017). 
Seawright J and Gerring J (2008) Case Selection Techniques in Case Study Research: A Menu of Qualitative and Quantitative Options. Political Research Quarterly 61(2): 294-308.

Shapiro J (1994) Disability Policy and the Media: A Stealth Civil Rights Movement Bypasses the Press and Defies Conventional Wisdom. Policy Studies Journal 22(1): 123-132. DOI: 10.1111/j.15410072.1994.tb02185.x.

Smith KB and Larimer CW (2016) The Public Policy Theory Primer. 3 edition. Boulder, Colorado: Westview Press.

Streeck W and Thelen K (2005) Introduction: Institutional Change in Advanced Political Economies. In: Streeck W and Thelen K (eds) Beyond Continuity: Institutional Change in Advanced Political Economies. New York, NY, USA: Oxford University Press, USA.

Sulewski JS, Timmons JC, Lyons O, et al. (2017) Organizational transformation to integrated employment and community life engagement. Journal of Vocational Rehabilitation 46(3): 313320. DOI: $10.3233 / J V R-170867$.

Thompson FJ and Burke C (2007) Executive Federalism and Medicaid Demonstration Waivers: Implications for Policy and Democratic Process. Journal of Health Politics, Policy \& Law 32(6): 971-1004. DOI: 10.1215/03616878-2007-039.

Tucker K, Feng H, Gruman C, et al. (2017) Improving competitive integrated employment for youth and young adults with disabilities: Findings from an evaluation of eight Partnerships in Employment Systems Change Projects. Journal of Vocational Rehabilitation 47(3): 277-294. DOI: 10.3233/JVR-170902.

U. S. Census Bureau (n.d.) American FactFinder - Results. Available at: http://factfinder.census.gov/faces/tableservices/jsf/pages/productview.xhtml?src=bkmk (accessed 16 October 2015).

University of Massachusetts Boston, Institute on Community Inclusion (n.d.) StateData.info: Population Data from the American Community Survey (Post 2007), Cognitive Disability. Available at: www.statedata.info.

University of Michigan Law School (n.d.) Civil Rights Litigation Clearinghouse: Searches=Olmstead Cases in Pennsylvania and Washington. Available at: https://www.clearinghouse.net (accessed 15 February 2018).

U.S. Department of Health and Human Services, Administration on Community Living (n.d.) AIDD Employment First Initiatives. Available at: /programs/youth-transitions/aidd-employment-firstinitiatives (accessed 25 April 2019).

U.S. Department of Justice, Civil Rights Division (n.d.) Olmstead: Community Integration for Everyone webpage. Available at: http://www.ada.gov/olmstead/ (accessed 10 March 2015).

U.S. Department of Labor (n.d.a.) Employment First webpage. Available at: http://www.dol.gov/odep/topics/EmploymentFirst.htm (accessed 15 March 2015).

U.S. Department of Labor (n.d.b.) Subminimum Wage. Available at: https://www.dol.gov/general/topic/wages/subminimumwage (accessed 20 August 2018). 
Van Slyke DM (2007) Agents or Stewards: Using Theory to Understand the Government-Nonprofit Social Service Contracting Relationship. Journal of Public Administration Research \& Theory 17(2): 157-187.

Washington Department of Social and Health Services (2004) WA Policy Directive 4.11. County Services for Working Age Adults. Available at: https://www.dshs.wa.gov/sites/default/files/DDA/dda/documents/policy/policy4.11.pdf (accessed 23 May 2017).

Washington Legislature (1998) Chapter 216 (SSB 6751). AN ACT Relating to stabilizing long-term care for persons with developmental disabilities living in the community and in residential habilitation centers. 1998 Regular Session. Available at:

http://app.leg.wa.gov/billsummary?BillNumber=6751\&Year=1997 (accessed 15 November 2017).

Washington Senate (2012) Chapter 49 (SSB 6384). AN ACT Relating to ensuring that persons with developmental disabilities be given the opportunity to transition to a community access program after enrollment in an employment program. Laws of 2012. Available at: http://app.leg.wa.gov/billsummary?BillNumber=6384\&Year=2012 (accessed 4 May 2017).

Washington State Department of Social and Health Services and Washington State Health Care Authority (2015) Washington State Transition Plan for New HCBS Rules.pdf. Available at:

https://www.dshs.wa.gov/sites/default/files/DDA/dda/documents/Washington\%20State\%20Trans ition\%20Plan\%20for\%20New\%20HCBS\%20Rules.pdf (accessed 17 November 2017).

Wehman P, Kregel J and Shafer M (1989) Emerging Trends in the National Supported Employment Initiative: A Preliminary Analysis of Twenty-Seven States. Available at: https://eric.ed.gov/?id=ED322660 (accessed 1 October 2018).

Weible CM (2008) Expert-Based Information and Policy Subsystems: A Review and Synthesis. Policy Studies Journal 36(4): 615-635. DOI: 10.1111/j.1541-0072.2008.00287.x.

Weible CM, Sabatier PA and McQueen K (2009) Themes and Variations: Taking Stock of the Advocacy Coalition Framework. Policy Studies Journal 37(1): 121-140. DOI: 10.1111/j.15410072.2008.00299.x.

Weible CM, Sabatier PA, Jenkins-Smith HC, et al. (2011) A Quarter Century of the Advocacy Coalition Framework: An Introduction to the Special Issue. Policy Studies Journal 39(3): 349-360. DOI: 10.1111/j.1541-0072.2011.00412.x.

Winsor JE, Hall AC, Butterworth J, et al. (2006) Pushing the Integrated Employment Agenda: Case Study Research in Washington State. June. Available at: http://www.communityinclusion.org/article.php?article_id=173 (accessed 2 May 2017).

Workman S (2015) The Dynamics of Bureaucracy in the U.S. Government: How Congress and Federal Agencies Process Information and Solve Problems. New York, NY: Cambridge University Press. 
Appendix A1: Sampling Frame

\begin{tabular}{|c|c|c|c|c|c|}
\hline \multicolumn{6}{|c|}{ Supported Employment and EF Policy Adoption by US State } \\
\hline $\begin{array}{c}\text { Proportion in } \\
\text { Supported } \\
\text { Employment: } \\
1999\end{array}$ & $\begin{array}{l}\text { Percentage Point } \\
\text { Change in } \\
\text { Proportion in } \\
\text { Supported } \\
\text { Employment: } \\
\text { 1999-14 }\end{array}$ & $\begin{array}{l}\text { EF policy } \\
\text { adoption }\end{array}$ & $\begin{array}{l}\text { Timing of } \\
\text { EF policy } \\
\text { adoption }\end{array}$ & $\begin{array}{c}\# \text { of } \\
\text { states }\end{array}$ & States** \\
\hline High & High & Yes & Early & 1 & WA \\
\hline High & High & Yes & Late & 1 & OK \\
\hline High & High & No & None & 4 & MA, MD, MO, VT \\
\hline High & Low & Yes & Early & 7 & $\begin{array}{c}\text { DE, FL, IA, KS, OH, } \\
\text { TX, UT }\end{array}$ \\
\hline High & Low & Yes & Late & 2 & IN, NV \\
\hline High & Low & No & None & 13 & $\begin{array}{c}\text { AL, AZ, CT, GA } \\
\text { ID, LA, KY, MI, } \\
\text { MN, NE, NY, SC, } \\
\text { SD }\end{array}$ \\
\hline Low & High & Yes & Early & 1 & VA \\
\hline Low & High & Yes & Late & 1 & MS \\
\hline Low & High & No & None & 4 & NC, NM, TN, WI \\
\hline Low & Low & Yes & Early & 3 & CA, IL, OR \\
\hline Low & Low & Yes & Late & 2 & PA, WY \\
\hline Low & Low & No & None & 2 & $\mathrm{CO}, \mathrm{NH}$ \\
\hline $\mathrm{n} / \mathrm{a}$ in & $r$ more of the select & $\mathrm{n}$ indicators & & 9 & $\begin{array}{c}\text { AK, AR, HI, ME, } \\
\text { MT, ND, NJ, RI, WV }\end{array}$ \\
\hline
\end{tabular}

High level: 1999 proportion above median (high initial SE proportion)

Low level: 1999 proportion below median (low initial SE proportion)

High change: 1999-2014 percentage point change below median

Low change: 1999-2014 percentage point change below median

Early $=$ Executive Order or Legislation adopted before 2014

Late $=$ Executive Order or Legislation adopted 2014 or later

*States in bold font adopted EF legislation. All others adopted via Executive Order. 


\section{Appendix A2: Interview Guides}

\section{State-level Telephone Interview Questions}

1) Please tell me about your background and your current role.

2) How would you describe your state's current approach to employment services and supports for individuals with I/DD, and important policies or practices? For my purposes, policies and practices can mean many things, from formal legislative action and rulemaking to the "business" of service provision to less formal norms and priorities.

3) Thinking back over the last fifteen to twenty years, since about 2000, what major changes to policies and practices have occurred, for better or worse, relating to employment services and supports in your state?

4) [AS NECESSARY, FOR THE 2-3 TOP CHANGES CITED ABOVE. ALSO ASK ABOUT EMPLOYMENT FIRST IF NOT MENTIONED.]:

a. What (specifically) changed and when did it occur?

b. What problem was the change intended to address?

c. Which stakeholders or groups were most heavily involved, and what was their position?

d. What were the main arguments for and against the change?

e. How did supporters and opponents attempt to influence the outcome?

f. What conditions or events were they key drivers of the change?

g. How were any differences resolved, if at all?

h. What role did you or your organization play in efforts to influence the outcome?

i. Were there any specific individuals who were essential to influencing the outcome?

5) With which groups does your organization collaborate most at the state level to influence policies and practices, and why? With which groups do you avoid collaborating, and why? How has this changed over the last fifteen to twenty years, if at all?

6) With which national groups does your organization collaborate or avoid collaborating, and why? How has this changed, if at all?

7) Is there anything else about your state's policies and practices related to employment services for individuals with I/DD that you'd like to tell me about?

8) Is there anyone else that you would recommend contacting about these issues? [IF YES, request name and organization] 


\section{National-level Telephone Interview Questions}

1) Please tell me a little bit about your background and your current position.

2) How would you describe current state-level approaches to providing employment services and supports to individuals with IDD, including important policies and practices? For my purposes, policies and practices can mean many things, from formal legislative action and rulemaking to the "business" of service provision to less formal norms and priorities.

3) Thinking back over the last fifteen to twenty years, since about 2000, what major changes to state-level policies, practices, and priorities have occurred, for better or worse, relating to employment services and supports? [AS NECESSARY, FOR THE 2-3 TOP CHANGES CITED ABOVE]:

a. What (specifically) changed and when?

b. To what degree did the change occur across states?

c. What problem was the change intended to address?

d. Who were the most involved stakeholders or groups, and what was their position?

e. What conditions or events were the key drivers of change?

f. What were the main arguments for and against the change?

g. How did supporters and opponents attempt to influence the outcome?

h. How were differences resolved, if at all?

i. What role did you or your organization play in efforts to influence the outcome?

j. Which states moved quickly to change? Which states resisted change?

4) With which national stakeholders or groups does your organization collaborate most to influence policies and practices related to employment services, and why? How has this changed over the last fifteen to twenty years, if at all?

5) With which groups do you avoid collaborating, and why? How has this changed over the last fifteen to twenty years, if at all?

6) Is there anything else about state-level policies, practices and priorities relating to employment services that you'd like to tell me about?

7) Is there anyone else that you would recommend contacting about these issues? [IF YES, request name and organization] 


\section{Appendix A3: Number of Completed Interviews by Stakeholder Type}

Table A3.1: Number of Completed Interviews by State and Stakeholder Type

\begin{tabular}{lcc}
\hline & Washington & Pennsylvania \\
\hline Government agencies & 4 & 6 \\
\hline $\begin{array}{l}\text { Interest group/advocacy } \\
\text { organizations }\end{array}$ & 8 & 2 \\
\hline Service providers & 4 & 3 \\
\hline Professional associations & 2 & 2 \\
\hline $\begin{array}{l}\text { Other (e.g., consultant, media, } \\
\text { lobbyist, etc) }\end{array}$ & 2 & 1 \\
\hline Total & 20 & 14
\end{tabular}




\section{Appendix A4: Detailed Codebook}

\begin{tabular}{|c|c|c|}
\hline \multicolumn{3}{|c|}{ Appendix A4.1: Codebook (Beliefs and Coalitions) } \\
\hline $\begin{array}{l}\text { Primary } \\
\text { Level }\end{array}$ & Secondary Level & Tertiary Level \\
\hline \multirow{6}{*}{ 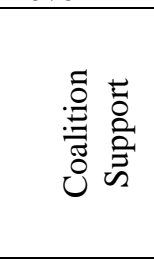 } & \multirow[t]{3}{*}{ Employment First } & Activity \\
\hline & & Support \\
\hline & & Reservations about support \\
\hline & \multirow[t]{3}{*}{ Choice } & Activity \\
\hline & & Support \\
\hline & & Reservation about support \\
\hline \multirow{8}{*}{ 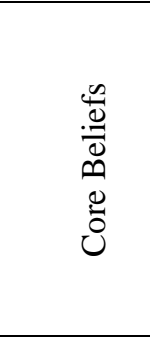 } & \multirow[t]{4}{*}{ Stakeholder Motivations } & Concern \\
\hline & & Self-interest \\
\hline & & Values \\
\hline & & Fear \\
\hline & \multirow[t]{2}{*}{ Value of Services } & Provision of services \\
\hline & & Individualization of services \\
\hline & \multirow[t]{2}{*}{ Government Authority } & Government prescription of services good \\
\hline & & Government prescription of services not good \\
\hline \multirow{29}{*}{ 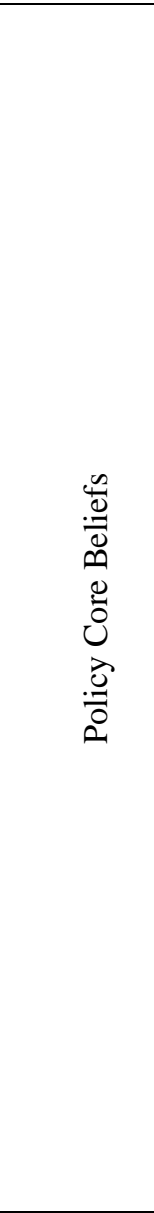 } & \multirow[t]{2}{*}{ Nature of the problem } & Individuals are underengaged \\
\hline & & Individuals are underemployed \\
\hline & \multirow[t]{11}{*}{ Cause of the problem } & Services are at risk \\
\hline & & Confusion about benefits \\
\hline & & Access to services \\
\hline & & Implementation \\
\hline & & Capacity to deliver services \\
\hline & & Individual skills \\
\hline & & Funding \\
\hline & & Economic opportunities \\
\hline & & Exposure to opportunities \\
\hline & & Services not available in area \\
\hline & & Low expectations \\
\hline & \multirow[t]{2}{*}{ Nature of capacity for work } & All can work \\
\hline & & Not all can work \\
\hline & \multirow[t]{9}{*}{ Priority outcomes for individuals } & Engaged \\
\hline & & Happy \\
\hline & & In community \\
\hline & & Independent \\
\hline & & Safe \\
\hline & & Wage \\
\hline & & Learning \\
\hline & & Self-determination \\
\hline & & Employment \\
\hline & \multirow[t]{3}{*}{ Priority outcomes for family } & Finances \\
\hline & & Respite \\
\hline & & Stability \\
\hline & \multirow[t]{2}{*}{ Priority target populations } & High-acuity \\
\hline & & Rural \\
\hline
\end{tabular}




\begin{tabular}{|c|c|c|}
\hline \multicolumn{3}{|c|}{ Table A4.1: Codebook (Beliefs and Coalitions) } \\
\hline $\begin{array}{c}\text { Primary } \\
\text { Level }\end{array}$ & Secondary Level & Tertiary Level \\
\hline \multirow{3}{*}{ 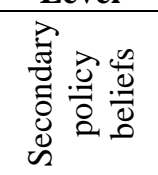 } & Data use & Data should be used to inform decisions \\
\hline & \multirow{2}{*}{ Data findings } & Data does not yield support for CIE \\
\hline & & Data yields support for CIE \\
\hline \multirow{5}{*}{ 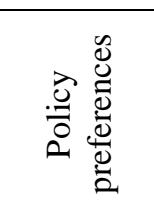 } & \multirow[t]{5}{*}{ Policy preferences } & Allow non-CIE services \\
\hline & & Address waitlist \\
\hline & & Provide a wide array of services \\
\hline & & Prioritize CIE \\
\hline & & Limit facility-based services \\
\hline \multirow{5}{*}{ 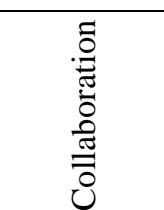 } & \multirow[t]{3}{*}{ Avoid collaboration } & Avoid EF \\
\hline & & Avoid Choice \\
\hline & & No avoidance \\
\hline & \multirow[t]{2}{*}{ Collaborate } & Collaborate EF \\
\hline & & Collaborate Choice \\
\hline
\end{tabular}




\begin{tabular}{|c|c|c|}
\hline Primary & Secondary Level & Tertiary Level \\
\hline \multirow{3}{*}{ 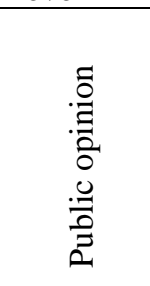 } & $\begin{array}{l}\text { Changes in opinion about sheltered } \\
\text { workshops }\end{array}$ & $\mathrm{n} / \mathrm{a}$ \\
\hline & Changes in other stakeholders' opinions & $\mathrm{n} / \mathrm{a}$ \\
\hline & Changes in consumer/family preferences & $\mathrm{n} / \mathrm{a}$ \\
\hline \multirow{2}{*}{ 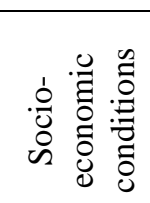 } & Changes in autism prevalence & $\mathrm{n} / \mathrm{a}$ \\
\hline & Recession-related changes & $\mathrm{n} / \mathrm{a}$ \\
\hline 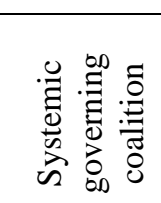 & Administration change & $\mathrm{n} / \mathrm{a}$ \\
\hline \multirow{2}{*}{ 离 } & DOJ Olmstead litigation & $\mathrm{n} / \mathrm{a}$ \\
\hline & EF policy decisions & $\mathrm{n} / \mathrm{a}$ \\
\hline \multirow{5}{*}{ 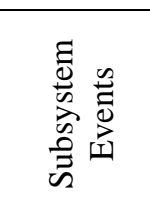 } & Locus of control & $\mathrm{n} / \mathrm{a}$ \\
\hline & Formal audits/reviews & $\mathrm{n} / \mathrm{a}$ \\
\hline & In-state litigation & $\mathrm{n} / \mathrm{a}$ \\
\hline & Institutional rules & $\mathrm{n} / \mathrm{a}$ \\
\hline & Performance accountability & $\mathrm{n} / \mathrm{a}$ \\
\hline \multirow{5}{*}{ 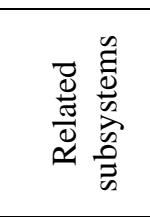 } & HCBS services for other disability types & $\mathrm{n} / \mathrm{a}$ \\
\hline & \begin{tabular}{|l|} 
Deinstitutionalization \\
\end{tabular} & $\mathrm{n} / \mathrm{a}$ \\
\hline & \begin{tabular}{|l|} 
K-12 education \\
\end{tabular} & $\mathrm{n} / \mathrm{a}$ \\
\hline & Minimum wage & $\mathrm{n} / \mathrm{a}$ \\
\hline & Caregiver training and reimbursement & $\mathrm{n} / \mathrm{a}$ \\
\hline \multirow{4}{*}{ 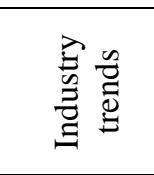 } & Assistive technology & $\mathrm{n} / \mathrm{a}$ \\
\hline & Automation & $\mathrm{n} / \mathrm{a}$ \\
\hline & Industry models & $\mathrm{n} / \mathrm{a}$ \\
\hline & Communication modes & $\mathrm{n} / \mathrm{a}$ \\
\hline \multirow{5}{*}{ 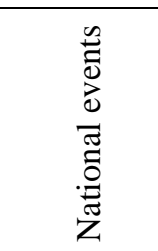 } & Healthcare & ACA/Medicaid funding \\
\hline & \multirow[t]{2}{*}{ Home and community-based services } & CMS sheltered workshop plan \\
\hline & & CMS transformation waiver renewal \\
\hline & Education & $\begin{array}{l}\text { Olmstead decision } \\
\text { High school transition }\end{array}$ \\
\hline & Workforce & WIOA legislation \\
\hline
\end{tabular}




\begin{tabular}{|c|c|c|}
\hline \multicolumn{3}{|c|}{ Table A4.3: Codebook (Resources Availability and Use) } \\
\hline $\begin{array}{l}\text { Primary } \\
\text { Level }\end{array}$ & Secondary Level & Tertiary Level \\
\hline \multirow{10}{*}{ 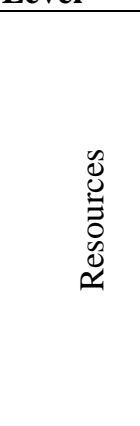 } & Formal authority & $\mathrm{n} / \mathrm{a}$ \\
\hline & \multirow[t]{3}{*}{ Information } & Aggregate data \\
\hline & & Anecdotal data \\
\hline & & Policy information \\
\hline & \multirow[t]{2}{*}{ Public opinion } & Broad public opinion \\
\hline & & Targeted stakeholders' opinions \\
\hline & Financial resources & $\mathrm{n} / \mathrm{a}$ \\
\hline & Mobilizable troops & $\mathrm{n} / \mathrm{a}$ \\
\hline & Skillful leadership & $\mathrm{n} / \mathrm{a}$ \\
\hline & Other resources & $\mathrm{n} / \mathrm{a}$ \\
\hline \multirow{5}{*}{ 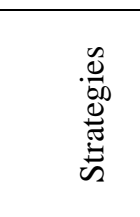 } & Arguing against opponent's position & $\mathrm{n} / \mathrm{a}$ \\
\hline & Convincing decision-makers & $\mathrm{n} / \mathrm{a}$ \\
\hline & Policy development & $\mathrm{n} / \mathrm{a}$ \\
\hline & Solidifying coalition membership & $\mathrm{n} / \mathrm{a}$ \\
\hline & Swaying public opinion & $\mathrm{n} / \mathrm{a}$ \\
\hline
\end{tabular}




\begin{tabular}{|c|c|c|}
\hline \multicolumn{3}{|c|}{ Table A4.4: Codebook (Policy change) } \\
\hline $\begin{array}{l}\text { Primary } \\
\text { Level }\end{array}$ & Secondary Level & Tertiary Level \\
\hline \multirow{8}{*}{ 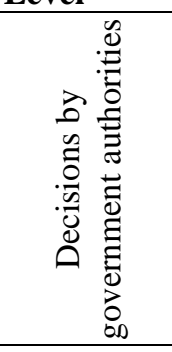 } & \multirow{2}{*}{ Executive Orders } & Disability-related \\
\hline & & Management-related \\
\hline & \multirow[t]{2}{*}{ Legislation (introduced) } & EF legislation \\
\hline & & Choice legislation \\
\hline & \multirow[t]{4}{*}{ Legislation (passed) } & CIE services \\
\hline & & Transition services \\
\hline & & Constitutional rules \\
\hline & & Operating budgets \\
\hline \multirow{12}{*}{ 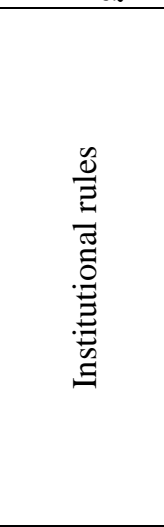 } & Informal rules/culture & $\mathrm{n} / \mathrm{a}$ \\
\hline & \multirow[t]{11}{*}{ Formal rules } & Accountability \\
\hline & & Staff certification \\
\hline & & Service eligibility \\
\hline & & Family of 1 \\
\hline & & Individualizing services \\
\hline & & Pathway to Employment \\
\hline & & Rate structures \\
\hline & & Sheltered workshop transition/closure \\
\hline & & Self-directed services \\
\hline & & Service delivery structure \\
\hline & & Service definitions \\
\hline \multirow{6}{*}{ 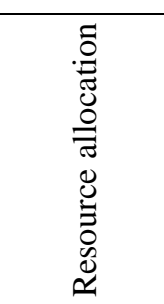 } & Overall resource levels & $\mathrm{n} / \mathrm{a}$ \\
\hline & Resource allocations to counties & $\mathrm{n} / \mathrm{a}$ \\
\hline & \multirow{4}{*}{$\begin{array}{l}\text { Resources directed to specific } \\
\text { purposes }\end{array}$} & For community access \\
\hline & & For capacity-building \\
\hline & & For employment services \\
\hline & & For transition services \\
\hline 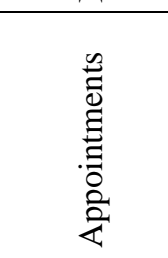 & State-level & $\mathrm{n} / \mathrm{a}$ \\
\hline \multirow{2}{*}{ 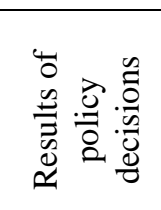 } & Policy outputs & $\mathrm{n} / \mathrm{a}$ \\
\hline & Policy outcomes & $\mathrm{n} / \mathrm{a}$ \\
\hline
\end{tabular}




\section{Appendix A5: Conditions Associated with Major Policy Changes}

\begin{tabular}{|c|c|c|}
\hline & Washington & Pennsylvania \\
\hline \multirow{5}{*}{ 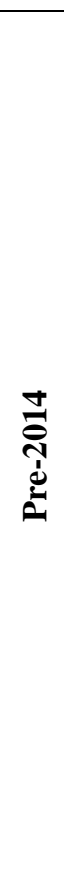 } & $\begin{array}{l}\text { Source(s) of change: } \\
\text { High degree of subsystem breakdown } \\
\text { High degree of subsystem attention }\end{array}$ & $\begin{array}{l}\text { Source(s) of change: } \\
\text { Low degree of subsystem breakdown } \\
\text { Low degree of subsystem attention }\end{array}$ \\
\hline & $\begin{array}{l}\text { Political opportunity: } \\
\text { High bureaucratic advocacy } \\
\text { High national support }\end{array}$ & $\begin{array}{l}\text { Political opportunity: } \\
\text { Low bureaucratic advocacy } \\
\text { Moderate national support }\end{array}$ \\
\hline & $\begin{array}{l}\text { Context: } \\
\text { High antecedent levels of CIE services }\end{array}$ & $\begin{array}{l}\text { Context: } \\
\text { Low antecedent levels of CIE services }\end{array}$ \\
\hline & $\begin{array}{l}\text { EF Resources/strategies: } \\
\text { Strong connection to allies in authority } \\
\text { High degree of mobilizable troops } \\
\text { Strong strategic use of information } \\
\text { Strong national support } \\
\text { Strong service provider support } \\
\text { High coalition membership }\end{array}$ & $\begin{array}{l}\text { EF Resources/strategies: } \\
\text { Weak connection to allies in authority } \\
\text { Low degree of mobilizable troops } \\
\text { Weak strategic use of information } \\
\text { Moderate national support } \\
\text { Weak service provider support } \\
\text { Low coalition membership }\end{array}$ \\
\hline & $\begin{array}{l}\text { Choice Resources/strategies: } \\
\text { Moderate connection to allies in authority } \\
\text { Low degree of mobilizable troops } \\
\text { Strong strategic use of information } \\
\text { Moderate national support } \\
\text { Low coalition membership }\end{array}$ & $\begin{array}{l}\text { Choice Resources/strategies: } \\
\text { Moderate connection to allies in authority } \\
\text { High degree of mobilizable troops } \\
\text { Weak strategic use of information } \\
\text { Moderate national support } \\
\text { High coalition membership }\end{array}$ \\
\hline \multirow{5}{*}{ 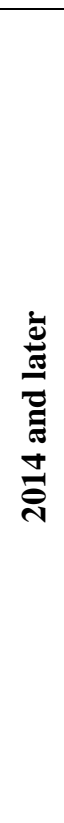 } & $\begin{array}{l}\text { Source(s) of change: } \\
\text { High degree of hierarchical guidance } \\
\text { High degree of subsystem attention }\end{array}$ & $\begin{array}{l}\text { Source(s) of change: } \\
\text { High degree of hierarchical guidance } \\
\text { High degree of subsystem attention }\end{array}$ \\
\hline & $\begin{array}{l}\text { Political opportunity: } \\
\text { High degree of bureaucratic advocacy }\end{array}$ & $\begin{array}{l}\text { Political opportunity: } \\
\text { Low degree of bureaucratic advocacy }\end{array}$ \\
\hline & $\begin{array}{l}\text { Context: } \\
\text { High antecedent levels of CIE services }\end{array}$ & $\begin{array}{l}\text { Context: } \\
\text { Low antecedent levels of CIE services }\end{array}$ \\
\hline & $\begin{array}{l}\text { EF Resources/strategies: } \\
\text { Strong connection to allies in authority } \\
\text { High degree of mobilizable troops } \\
\text { Strong strategic use of information } \\
\text { Strong national support } \\
\text { High coalition membership }\end{array}$ & $\begin{array}{l}\text { EF Resources/strategies: } \\
\text { Strong connection to allies in authority } \\
\text { High degree of mobilizable troops } \\
\text { Strong strategic use of information } \\
\text { Strong national support } \\
\text { High coalition membership }\end{array}$ \\
\hline & $\begin{array}{l}\text { Choice Resources/strategies: } \\
\text { Moderate connection to allies in authority } \\
\text { Moderate degree of mobilizable troops } \\
\text { Strong strategic use of information } \\
\text { Moderate national support } \\
\text { Low coalition membership }\end{array}$ & $\begin{array}{l}\text { Choice Resources/strategies: } \\
\text { Moderate connection to allies in authority } \\
\text { Strong degree of mobilizable troops } \\
\text { Strong strategic use of information } \\
\text { Moderate national support } \\
\text { Moderate coalition membership }\end{array}$ \\
\hline
\end{tabular}

